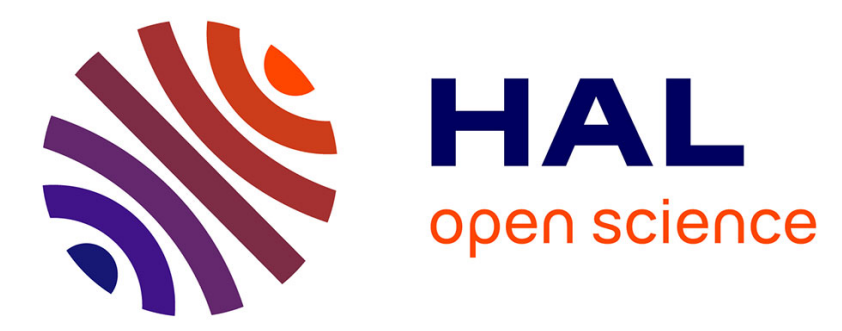

\title{
Palaeomagnetism of the early Palaeoproterozoic, volcanic Hekpoort Formation (Transvaal Supergroup) of the Kaapvaal craton, South Africa
}

F Humbert, L Sonnette, M O de Kock, P Robion, C S Horng, A Cousture, H Wabo

\section{- To cite this version:}

F Humbert, L Sonnette, M O de Kock, P Robion, C S Horng, et al.. Palaeomagnetism of the early Palaeoproterozoic, volcanic Hekpoort Formation (Transvaal Supergroup) of the Kaapvaal craton, South Africa. Geophysical Journal International, 2017, 209, pp.842 - 865. 10.1093/gji/ggx055 . hal03264150

\section{HAL Id: hal-03264150 \\ https://hal.science/hal-03264150}

Submitted on 17 Jun 2021

HAL is a multi-disciplinary open access archive for the deposit and dissemination of scientific research documents, whether they are published or not. The documents may come from teaching and research institutions in France or abroad, or from public or private research centers.
L'archive ouverte pluridisciplinaire HAL, est destinée au dépôt et à la diffusion de documents scientifiques de niveau recherche, publiés ou non, émanant des établissements d'enseignement et de recherche français ou étrangers, des laboratoires publics ou privés. 


\title{
Palaeomagnetism of the early Palaeoproterozoic, volcanic Hekpoort Formation (Transvaal Supergroup) of the Kaapvaal craton, South Africa
}

\author{
F. Humbert, ${ }^{1}$ L. Sonnette, ${ }^{2,3}$ M.O. de Kock, ${ }^{1}$ P. Robion, ${ }^{4}$ C.S. Horng, ${ }^{2}$ A. Cousture ${ }^{5}$ \\ and $\mathrm{H}$. Wabo ${ }^{1}$ \\ ${ }^{1}$ Department of Geology, University of Johannesburg, PO Box 524, Auckland Park 2006, Johannesburg, South Africa. E-mail: humbert.fabien@gmail.com \\ ${ }^{2}$ Institute of Earth Sciences, Academia Sinica, 128 Academia Road, Section 2, Taipei 115, Taiwan \\ ${ }^{3}$ Laboratoire d'Hydrogéologie, Université de Corse Pascal Paoli, Campus Grimaldi, BP 52, F-20250 Corte, France \\ ${ }^{4}$ Laboratoire Géosciences et Environnement Cergy, Université de Cergy-Pontoise, 5 Mail Gay-Lussac, Neuville-sur-Oise, F-95031 Cergy-Pontoise, France \\ ${ }^{5}$ Laboratoire de Mécanique et Matériaux du Génie Civil, Institut des Matériaux, Université de Cergy-Pontoise, 5 Mail Gay-Lussac, Neuville-sur-Oise, \\ F-95031 Cergy-Pontoise, France
}

Accepted 2017 February 13. Received 2017 February 7; in original form 2017 January 9

\section{S U M M A R Y}

The Kaapvaal craton (South Africa) was the host of several major magmatic events during the Palaeoproterozoic, including the volcanic Hekpoort and Ongeluk Formations. Their possible comagmatic origin is the subject of a long debate. We performed a palaeomagnetic study of the Hekpoort Formation to be compared with the available palaeopole of the Ongeluk Formation, but also to contribute to the apparent polar wander path of the Kaapvaal craton. Characterization of magnetic mineralogy by three-axis thermal demagnetization of isothermal remanent magnetization and magnetic susceptibility versus temperature points out magnetite as the main remanence carrier in most samples.

Five magnetic components were identified in total, of which the least stable (HKE) near parallels the present geomagnetic field. At higher levels of demagnetization (above $400{ }^{\circ} \mathrm{C}$ ), two components (HKD and HKC) are identified as thermoviscous overprints likely related to the Karoo large igneous province (LIP) and a magmatic event which occurred between the emplacement of the $\sim 2055$ Ma Bushveld Complex and HKD (possibly linked to the Umkondo LIP), respectively. This LIP is known to be associated with extensive remagnetization. The second most stable component HKB was also revealed at higher steps of thermal and alternative-field treatment. The HKB palaeopole (latitude $=28.4^{\circ} \mathrm{N}$ and longitude $=54^{\circ} \mathrm{E}$ ) is similar to those reported from the Bushveld Complex ( $2055 \mathrm{Ma})$ and the Vredefort impact structure $(\sim 2023 \mathrm{Ma})$. A potentially primary remanence direction (HKA; declination $=337^{\circ}$, inclination $=80^{\circ}$ and $\alpha=6.2^{\circ}$ ) was identified in most sites during the highest levels of thermal demagnetization. Note that the HKA pole position (latitude $=-44^{\circ} \mathrm{N}$ and longitude $=40^{\circ} \mathrm{E}$ ) is significantly different from the palaeopole for the Ongeluk Formation (latitude $=-0.5^{\circ} \mathrm{N}$ and longitude $=107^{\circ} \mathrm{E}$ ). Although, the primary nature of HKA is supported by positive fold and reversal tests, we cannot exclude the possibility that this component represents an overprint. HKA is, however, most likely older than $\sim 2.0$ Ga given its anteriority to HKB components.

Key words: Palaeomagnetism; Remagnetization; Rock and mineral magnetism; Cratons; Large igneous provinces; Africa.

\section{INTRODUCTION}

The Kaapvaal craton is one of the best preserved Archean cratons (Fig. 1), showing an almost complete record of Palaeoarchean to Palaeoproterozoic sedimentation, punctuated by several largescale episodes of magmatic activity (e.g. Johnson et al. 2006). The Palaeoproterozoic units of the Kaapvaal craton has been subject to numerous palaeomagnetic studies (e.g. Evans et al. 2002; de Kock et al. 2009a; Letts et al. 2010). The Transvaal Supergroup (Fig. 2) corresponds to the longest period of near continuous deposition on the craton $(\sim 2.7-2.05 \mathrm{Ga})$ during the Palaeoproterozoic. Only one primary pole, from the volcanic Ongeluk Formation of the western Kaapvaal craton (Evans et al. 1997), is convincingly established for the succession. No similar studies have 


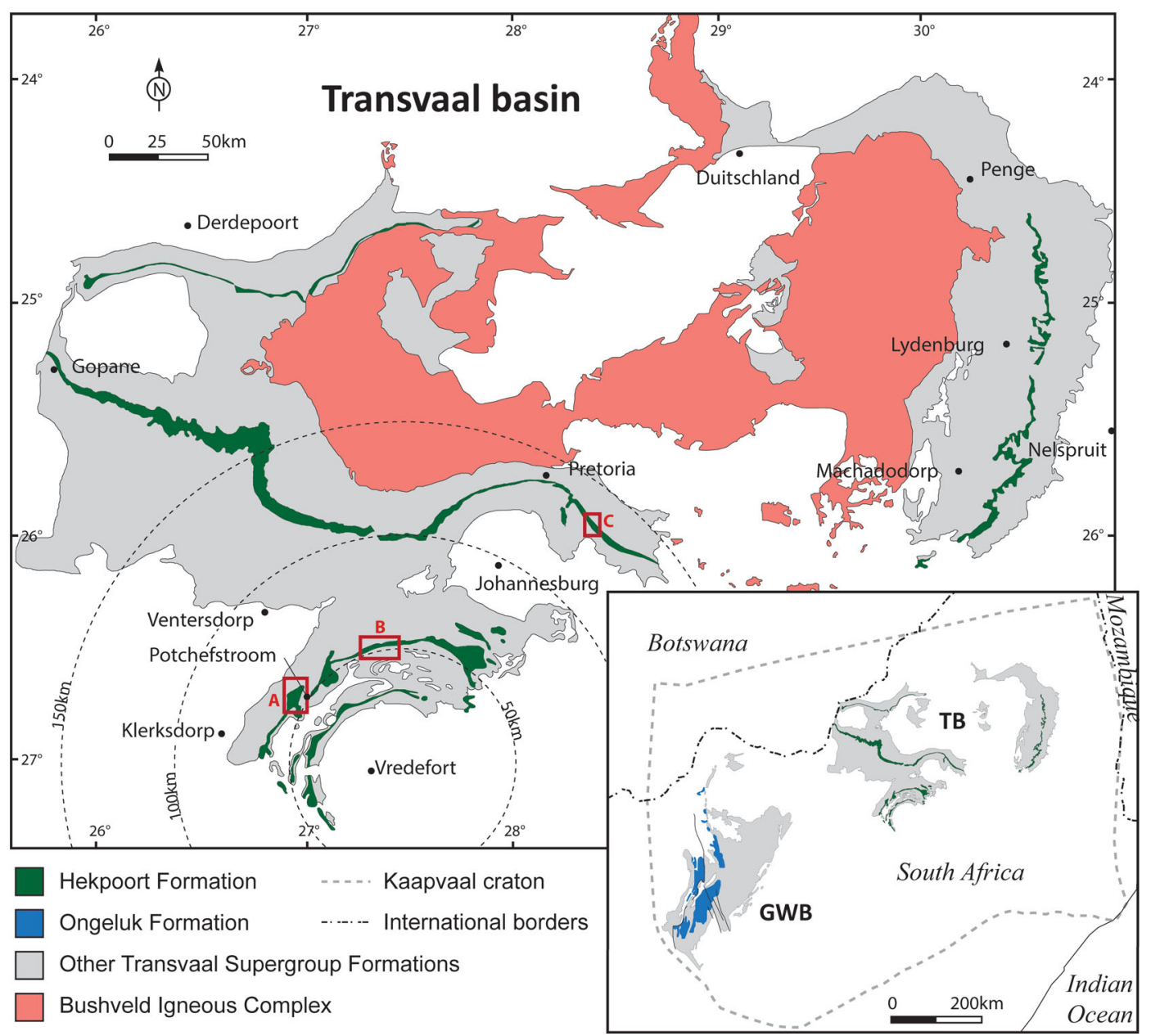

Figure 1. Distribution of the outcrops of the Bushveld Complex and the Transvaal Supergroup with emphasis of the Hekpoort lava formation in the Transvaal basin (TB) and the Ongeluk lava formation in the Griqualand West basins (GWB); compiled from 1:250 000 South African geological maps. The location of both basins inside the Kaapvaal Craton is specified in the right bottom. The Bushveld Complex represented here includes the Rooiberg Group, the Rustenberg layered Suite, the Rashoop Granophyre and the Lebowa Granite. The dashed portion of circles represent the areas at 50, 100 and $150 \mathrm{~km}$ from the centre of the Vredefort impact structure. The red rectangles represent the location of the main sampled areas (see Fig. 4 for more details).

ever been attempted on the Hekpoort Formation, interpreted by some authors as the stratigraphic equivalent of the Ongeluk Formation on the central Kaapvaal craton (e.g. Cornell et al. 1996). Here, we present palaeomagnetic results obtained from different locations of the Hekpoort Formation. In addition to demagnetization, we characterized by several methods the magnetic mineralogy of our samples for a better understanding of their magnetic history. Secondary magnetizations or overprints can provide useful information on the alteration history of the Hekpoort Formation through time.

Palaeomagnetic characterization of the Hekpoort Formation and comparison thereof with the Ongeluk Formation are essential to better understand the temporal and structural evolution of the Transvaal basin. The Transvaal Supergroup is divided into three preservational basins (Fig. 1) namely, the Griqualand West basin on the western Kaapvaal craton, and the Kanye and Transvaal basins on the north central Kaapvaal craton (e.g. Eriksson et al. 1993, 2006; Beukes et al. 2002). Lithological correlation is possible between the basins of Kanye and Transvaal (supposed to be one unique basin; e.g. Eriksson et al. 2006). The Kanye's the Taupone Group correlates well with the Chuniespoort Group of the Transvaal as well as with the stratigraphic lower sections of the Griqualand West basin (i.e. the Ghaap Group). Correlation, however, becomes more complex between the stratigraphic upper sections of these basins (i.e. the Pretoria and Segwagwa Groups) and the upper parts of the succession preserved in the Griqualand West basin (i.e. Postmasburg Group), which may have had an independent geodynamic and temporal evolution (Fig. 2).

The hypothesis that the Ongeluk and Hekpoort Formations are comagmatic is ingrained in South African stratigraphy since the work of du Toit (1926). Despite divergent mediums of intrusion for the two formations (subaquaeous and subaerial; Moore et al. 2001; Lenhardt et al. 2012), their correlation is seemingly supported by detrital zircon U-Pb geochronology (Cornell et al. 1996; Schröder et al. 2016; Zeh et al. 2016), geochemical similarity (Cornell et al. 1996; Oberholzer \& Eriksson 2000; Humbert et al., in preparation) and stratigraphically (e.g. Eriksson et al. 1993; Beukes et al. 2002; Gutzmer et al. 2003). However, stratigraphic arguments (Moore et al. 2001; Hoffman 2013), carbonate $\mathrm{Pb}-\mathrm{Pb}$ and $\mathrm{U}-\mathrm{Pb}$ geochronological results (Bau et al. 1999; Fairey et al. 2013), detrital zircon grains U-Pb geochronological results (Moore et al. 2012) and more recently, baddeleyite $\mathrm{U}-\mathrm{Pb}$ geochronological results (Gumsley et al. 2016) have questioned this correlation, by demonstrating the Ongeluk Formation to be $\sim 200 \mathrm{Ma}$ older. It would thus be quite interesting to illustrate if the palaeomagnetic data of the two formations are then in agreement with such age difference or not. 


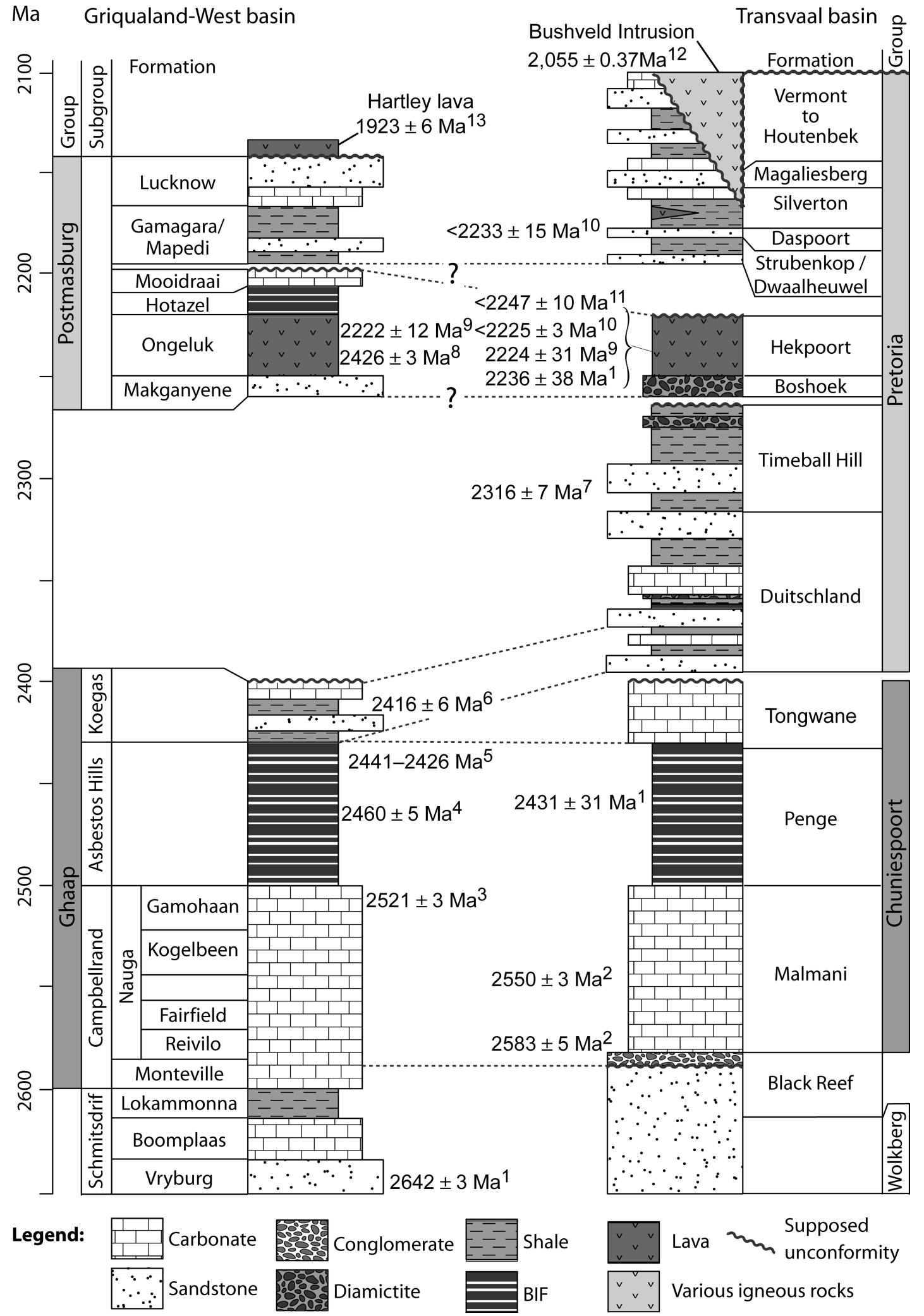

Figure 2. 'Traditional' chronostratigraphy of the Transvaal Supergroup (based on Beukes et al. 2002; Dorland 2004; Guo et al. 2009). The age dates are from: (1) Walraven \& Martini (1995), (2) Martin et al. (1998), (3) Sumner \& Bowring (1996), (4) Pickard (2003), (5) Kampmann et al. (2015), (6) Gutzmer \& Beukes (1998), (7) Hannah et al. (2004), (8) Gumsley et al. (2016, 2017), (9) Cornell et al. (1996), (10) Dorland (2004), (11) Schröder et al. (2016), (12) Zeh et al. (2015) and (13) Alebouyeh Semami et al. (2016). The Kanye basin stratigraphy is not represented. 


\section{GEOLOGICAL SETTING}

\subsection{The Pretoria Group}

The succession preserved in the three erosional basins of the Transvaal Supergroup (i.e. Transvaal, Kanye and Griqualand West basins) is generally similar, with correlation being best for the lower chemical sedimentary units, and poorest for the upper sedimentary and volcanic lithologies. Within the Transvaal basin of the central Kaapvaal craton, the Transvaal Supergroup is subdivided into the chemical sedimentary lithologies of Chuniespoort Group at the base and the predominantly clastic Pretoria Group at the top of the succession (Fig. 2). The lowermost Pretoria Group is represented by the Duitschland/Rooihoogte and Timeball Hill formations, which is developed on the Chunniespoort Group carbonates and banded iron formation with a marked unconformity (Eriksson et al. 2006; Schröder et al. 2016). The Timeball Hill is overlain by the fluvioglacial Boshoek Formation and volcanic Hekpoort Formation (Eriksson et al. 2006). The upper part of the Hekpoort Formation is in most places erosionally removed by the unconformity at the base of the fluvial Dwaalheuwel Formation quartzite. The upper part of the Hekpoort is represented by an oxic palaeosol developed in association with the unconformity at the base of the Dwaalheuwel Formation (Eriksson \& Cheney 1992; Yang \& Holland 2003). The Strubenkop Formation overlies the Dwaalheuwel Formation. Like for the rest of the upper part of the Pretoria Group, the Dwaalheuwel and Strubenkop formations are represented by quartzite and shale units deposited in a shallowing basin (Eriksson et al. 2006).

The Pretoria Group is intruded and covered by $2054.89 \pm$ $0.37 \mathrm{Ma}$ (Zeh et al. 2015) intrusions of the Bushveld Complex (Figs 1 and 2), and is only exposed along the margins thereof in a number of floor- and roof attached 'fragments' (Hartzer 1995) to the northeast and northwest of Pretoria, and in a basin-marginal main outcrop zone. The Pretoria Group was subjected to low grade to severe contact metamorphism in the vicinity of the Bushveld Complex (Eriksson et al. 2006).

\subsection{The Hekpoort Formation}

The 300-830 m volcanic Hekpoort Formation in the Transvaal basin crops out over an area of ca. $100000 \mathrm{~km}^{2}$ (Fig. 1; Lenhardt et al. 2012). Several concordant ages exist for the Hekpoort Formation, obtained by direct dating of lavas, $2236 \pm 38 \mathrm{Ma}$ (whole rock $\mathrm{Pb}-$ $\mathrm{Pb}$ isochron; Cornell et al. 1996) and $2224 \pm 21 \mathrm{Ma}$ (whole-rock $\mathrm{Rb}-\mathrm{Sr}$ isochron; Walraven \& Martini 1995), or by $\mathrm{U} / \mathrm{Pb}$ dating on SHRIMP of detrital zircons in palaeosols/interbedded sedimentary units included into the formation: $2225 \pm 3 \mathrm{Ma}$ (Dorland 2004) and $2247 \pm 10 \mathrm{Ma}$ (Schroeder et al. 2016). In most parts of the Transvaal basin, the Hekpoort Formation sharply overlies the fluvially and alluvially deposited Boshoek conglomerates and sandstones with a sharp contact (Fig. 2; Cheney 1996), and is unconformably succeeded by the Dwaalheuwel continental sandstones (Fig. 3a; Eriksson et al. 1993). In the central-southern parts of the basin, the Hekpoort Formation sharply overlies mudrocks of the Timeball Hill Formation, and is similarly overlain by Strubenkop Formation mudrocks.

The Hekpoort Formation dips gently to the N-NW at $c a .15^{\circ}$ and is characterized by a complex interplay of subaerial lava flows (Fig. 3b), pyroclastic deposits, and their reworked counterparts (Oberholzer 1995) representing deposition in a subaerial palaeoenvironment (e.g. Button 1973; Eriksson \& Reczko 1995;
Oberholzer 1995). Although there has been no regional study so far to establish the proportions of lava flows and volcaniclastic detritus in the Hekpoort Formation, the lava flows predominate according Sharpe et al. (1983) and our own observations. Button (1973) and Oberholzer \& Eriksson (2000) argue that volcanoclastic rocks present a significant portion of the lithology of the Hekpoort Formation. Yet, we only discovered two local outcrops of volcanoclastite in the whole studied area (Fig. 3c), only one of such site (GCE-A) located in the eastern part of Pretoria (Fig. 4), was sampled in such type of rock.

\subsection{The Ongeluk Formation}

In the Griqualand West basin, the Ongeluk Formation (Fig. 1), which belongs to the Postmasburg Group (Fig. 2), is characterized by an up to $900 \mathrm{~m}$ thick succession of massive basalts, pillow lavas and hyaloclastites indicating terrestrial and subaqueous extrusion of the volcanic rocks along the submerged western margin of the Kaapvaal craton (e.g. Cornell et al. 1996). The Ongeluk Formation disconformably overlies the Makganyene Formation glacigenic lithologies (Altermann \& Hälbich 1991) and is overlain by banded iron formations, manganese formations and dolostones that constitute the Hotazel and Mooidrai formations (Fig. 2).

The Ongeluk Formation age was first estimated at $2222 \pm 13 \mathrm{Ma}$ (whole rock $\mathrm{Pb}-\mathrm{Pb}$ isochron; Cornell et al. 1996), thus equivalent than that of the Hekpoort Formation (Fig. 2). Yet, Gumsley et al. $(2016,2017)$ reinterpreted the age of the formation to actually be $2426 \pm 3 \mathrm{Ma}$ by baddeleyite U-Pb dating, assumed to be more accurate than a whole rock dating. Note that this $\sim 2426$ Ma age also supports the ages of the Mooidraai Dolomite Formation above the Ongeluk Formation: $2394 \pm 26 \mathrm{Ma}$ (whole rock $\mathrm{Pb}-\mathrm{Pb}$ isochron on carbonates; Bau et al. 1999) and $2392 \pm 23 \mathrm{Ma}$ (whole rock U$\mathrm{Pb}$ isochron; Fairey et al. 2013). A different model of correlation between the Postmasburg and the Pretoria Groups (different from what is presented in Fig. 2) taking in account the new age of the Ongeluk Formation and the palaeomagnetic results of this study, will be presented in the end of this paper.

\subsection{The Bushveld Complex and the Vredefort impact structure}

The Bushveld Complex (Fig. 1) is the world's largest known layered mafic intrusion $\left(\sim 0.5-1 \times 106 \mathrm{~km}^{3}\right.$; e.g. Letts et al. 2009). Magmatism in the province was heralded by extrusion of the vast, basaltic to rhyolitic lavas. The magmatic province as a whole, thus comprises the volcanosedimentary Rooiberg Group ( 2061-2060 Ga; Rajesh et al. 2013), the mafic-layered rocks of the Bushveld Complex per se (the Rustenberg Layered Suite; $2054.89 \pm 0.37 \mathrm{Ma}$; Zeh et al. 2015), marginal pre- and synBushveld sills and intrusions (Frick 1973), the Lebowa Granite (2054 \pm 2 Ma; Walraven \& Hattingh 1993) and the Rashoop Granophyre suites (2053 $\pm 12 \mathrm{Ma}$; Coertze et al. 1978). In addition to contact metamorphism (e.g. Lenhardt et al. 2012), the intrusion of the Bushveld Complex induced a flexural folding of the Transvaal Supergroup units immediately north of the Johannesburg Dome (Eriksson et al. 2006).

The $2023 \pm 4$ Ma Vredefort impact structure (Kamo et al. 1996) represents the vestiges of an immense (250-300 km original diameter) impact crater (Henkel \& Reimold 1998), which includes the southwestern part of the Bushveld Complex and all the central and southern outcrops of the Hekpoort Formation (Fig. 1). The centre of 

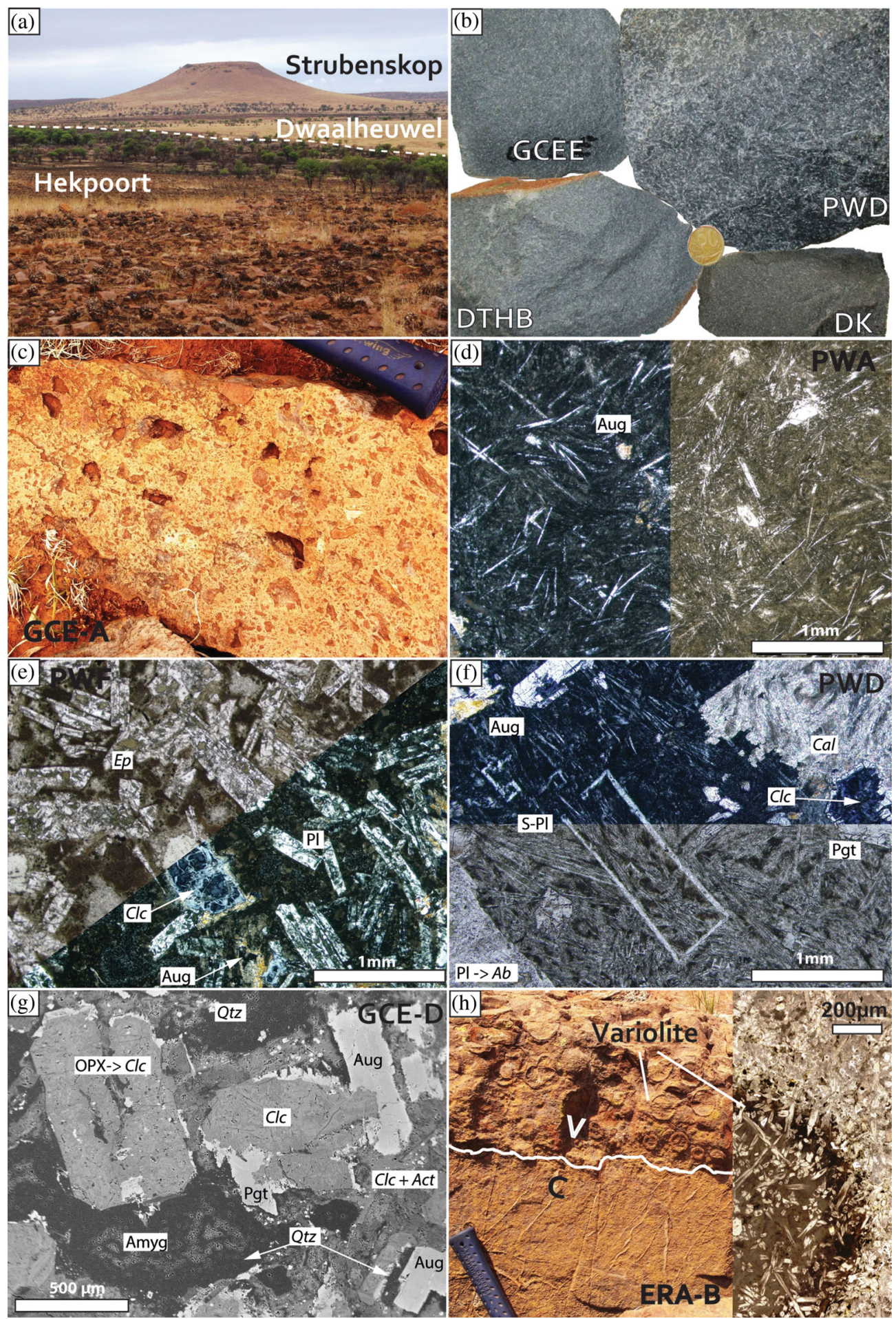

Figure 3. (a) Representative Hekpoort lava which in the most case correspond to a soil with scattered lava boulders. This picture also presents the contact between the Hekpoort Formation and the outlier of the Dwaalheuwel and Strubenkop formations. (b) Typical fresh cuts of the Hekpoort lava rocks, from aphanitic (DK) to hemicrystalline texture (PWD; see the text for more explanation). Most of the samples are showing an intersertal texture (DTHB and GCEE). (c) Example of volcanoclastite. This sample is not a fresh cut of the outcrop but several angular clasts remain easily visible. Hammer for scale. (d)-(f) thin sections in PPL and XPL mode showing detail of a microlitic (hyalopilitic) texture (d), an intersertal texture showing euhedral plagioclases (principally), orthopyroxenes (pseudomorphosed into clinochlore) and clinopyroxenes (e), and a microlitic texture (f) surrounding the plagioclase phenocrysts shown in (b). (g) Backscattered image of showing altered euhedral pyroxenes in between two amygdales (amyg) filled by quartz. Primary minerals: Aug = augite; $\mathrm{Opx}=$ orthopyroxene; $\mathrm{Pl}=$ plagioclase; $\mathrm{Pgt}=$ pigeonite; $\mathrm{S}-\mathrm{Pl}=$ skeletal plagioclase. Secondary minerals (italic in the figures): Act $=$ actinolite; $\mathrm{Cal}=\mathrm{calcite}$; $\mathrm{Clc}=$ clinochlore; $\mathrm{Ep}=$ epidote. (h) Example of individual variolitic flow in the ERA sites (left), characterized by an upper level rich in variolites (V layers) and a lower level devoid in variolite and sometimes showing what appear to be cooling columns (C layers). In the right part, a detail of one V-layer from a thin section scan in PPL colour, showing a portion of a variolite (dark brawn) surrounded by groundmass (light brawn). Such layers are rich in skeletal clinopyroxenes (needles easily visible inside the variolites but present everywhere), while the variolites are composed of an agglomeration of acicular clinopyroxenes $(1 \mu \mathrm{m}$ of thickness). The groundmass, assumed to be originally glassy, is partly devitrified. 

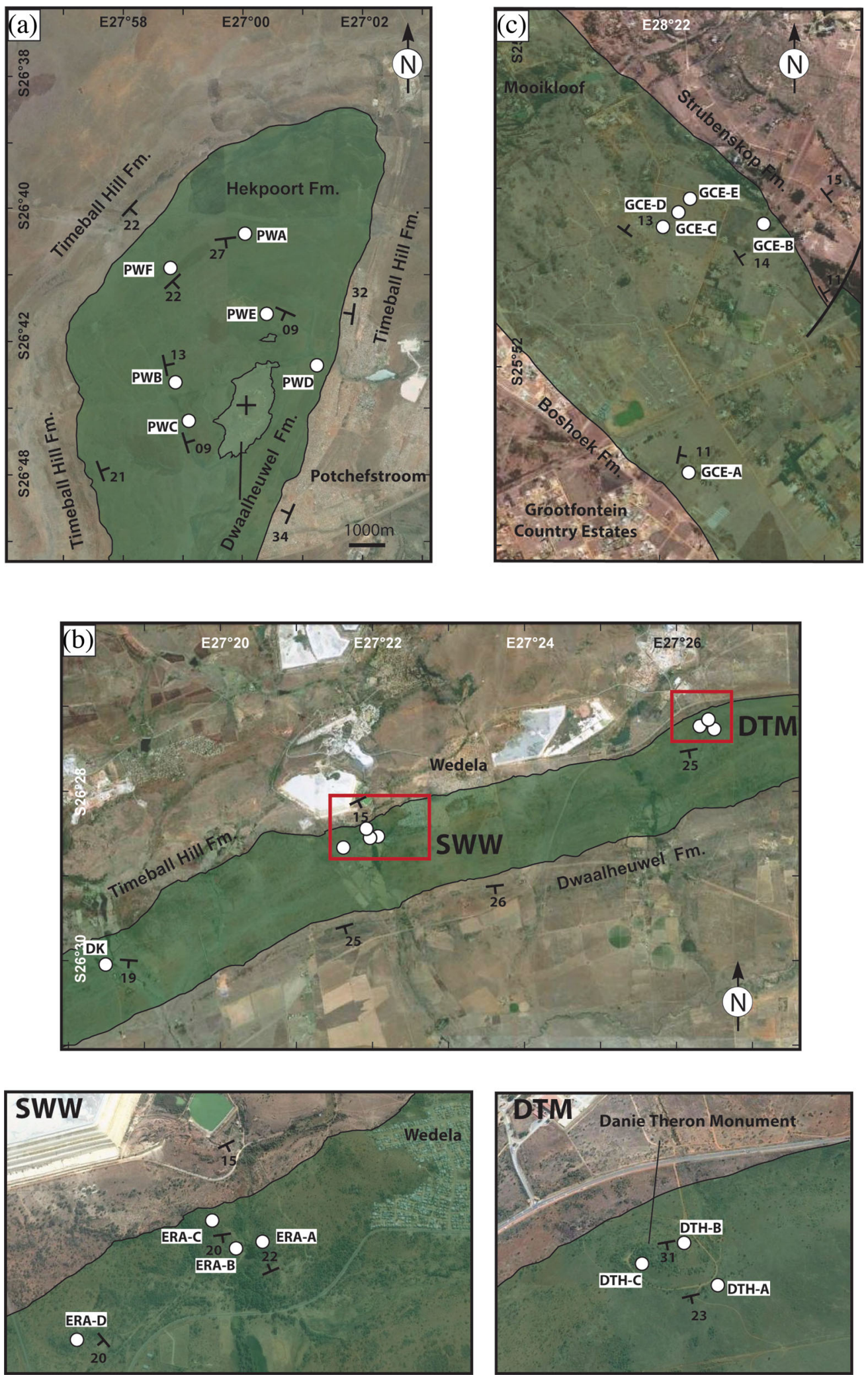

Figure 4. Location of all the 19 sites (white dots), regrouped following the main sampled areas: the Potchefstroom syncline (a), the area of Wedela (b) with two close-ups, respectively, the southwestern part of Wedela (ERA) and Danie Theron Monument (DTH), and the area of Mooikloof (c).

the structure is composed by a ca. $40 \mathrm{~km}$ dome, centred at $27^{\circ} \mathrm{S}$ and $27^{\circ} 30^{\prime} \mathrm{E}$, is located about $120 \mathrm{~km}$ southwest of Johannesburg. This dome comprises a wide core of Palaeo- to Meso-Archean granitoids (granites, granitic gneisses and migmatites) that is surrounded in the west, north and east sectors by a $15-20 \mathrm{~km}$ wide collar of up- and overturned Meso-Archean to Palaeoproterozoic supracrustal strata, which includes the Transvaal Supergroup rocks (Henkel \& Reimold 1998). 
Table 1. Summary of sampling site information. $n=$ number of different samples measured by each site.

\begin{tabular}{|c|c|c|c|c|c|c|}
\hline \multirow[b]{2}{*}{ Area } & \multirow[b]{2}{*}{ Sites } & \multicolumn{2}{|c|}{ Locality } & \multirow[b]{2}{*}{$\mathrm{N}$} & \multirow[b]{2}{*}{ Lithology } & \multirow[b]{2}{*}{ Bedding (strike/dip) } \\
\hline & & S & $\mathrm{E}$ & & & \\
\hline Potch syncline & PWA & $26^{\circ} 40^{\prime} 27.43^{\prime \prime}$ & $27^{\circ} 22^{\prime} 04.70^{\prime \prime}$ & 19 & Lava & $83^{\circ} / 27^{\circ}$ \\
\hline Potch syncline & PWB & $26^{\circ} 42^{\prime} 44.32^{\prime \prime}$ & $26^{\circ} 58^{\prime} 54.54^{\prime \prime}$ & 9 & Lava & $348^{\circ} / 13^{\circ}$ \\
\hline Potch syncline & PWC & $26^{\circ} 42^{\prime} 54.63^{\prime \prime}$ & $26^{\circ} 58^{\prime} 58.89^{\prime \prime}$ & 11 & Lava & $343^{\circ} / 09^{\circ}$ \\
\hline Potch syncline & PWD & $26^{\circ} 42^{\prime} 25.83^{\prime \prime}$ & $27^{\circ} 01^{\prime} 21.52^{\prime \prime}$ & 9 & Lava (dyke?) & $206^{\circ} / 32^{\circ}$ \\
\hline Potch syncline & PWE & $26^{\circ} 41^{\prime} 37.37^{\prime \prime}$ & $27^{\circ} 00^{\prime} 14.48^{\prime \prime}$ & 12 & Lava & $114^{\circ} / 09^{\circ}$ \\
\hline Potch syncline & PWF & $26^{\circ} 40^{\prime} 28.28^{\prime \prime}$ & $26^{\circ} 58^{\prime} 57.97^{\prime \prime}$ & 8 & Lava & $47^{\circ} / 22^{\circ}$ \\
\hline Wedela & DTH-A & $26^{\circ} 27^{\prime} 10.28^{\prime \prime}$ & $27^{\circ} 26^{\prime} 25.26^{\prime \prime}$ & 11 & Lava & $76^{\circ} / 24^{\circ}$ \\
\hline Wedela & DTH-B & $26^{\circ} 27^{\prime} 07.10^{\prime \prime}$ & $27^{\circ} 26^{\prime} 22.15^{\prime \prime}$ & 16 & Lava & $80^{\circ} / 31^{\circ}$ \\
\hline Wedela & DTH-C & $26^{\circ} 27^{\prime} 08.26^{\prime \prime}$ & $27^{\circ} 26^{\prime} 15.21^{\prime \prime}$ & 17 & Lava & $84^{\circ} / 26^{\circ}$ \\
\hline Wedela & ERA-A & $26^{\circ} 28^{\prime} 24.38^{\prime \prime}$ & $27^{\circ} 22^{\prime} 04.70^{\prime \prime}$ & 15 & Variolitic lava & $257^{\circ} / 22^{\circ}$ \\
\hline Wedela & ERA-B & $26^{\circ} 28^{\prime} 22.97^{\prime \prime}$ & $27^{\circ} 22^{\prime} 04.91^{\prime \prime}$ & 17 & Variolitic lava & $208^{\circ} / 20^{\circ}$ \\
\hline Wedela & ERA-C & $26^{\circ} 28^{\prime} 19.26^{\prime \prime}$ & $27^{\circ} 22^{\prime} 01.88^{\prime \prime}$ & 14 & Variolitic lava & $101^{\circ} / 32^{\circ}$ \\
\hline Wedela & ERA-D & $26^{\circ} 28^{\prime} 36.45^{\prime \prime}$ & $27^{\circ} 22^{\prime} 37.81^{\prime \prime}$ & 19 & Variolitic lava & $140^{\circ} / 20^{\circ}$ \\
\hline Wedela & DK & $26^{\circ} 29^{\prime} 57.98^{\prime \prime}$ & $27^{\circ} 22^{\prime} 40.14^{\prime \prime}$ & 12 & Aphanitic lava & $94^{\circ} / 19^{\circ}$ \\
\hline Mooikloof & GCEA & $25^{\circ} 52^{\prime} 35.00^{\prime \prime}$ & $28^{\circ} 22^{\prime} 06.20^{\prime \prime}$ & 9 & Volcanoclastite & $11^{\circ} / 16^{\circ}$ \\
\hline Mooikloof & GCEB & $25^{\circ} 51^{\prime} 10.70^{\prime \prime}$ & $28^{\circ} 22^{\prime} 33.40^{\prime \prime}$ & 9 & Lava & $328^{\circ} / 14^{\circ}$ \\
\hline Mooikloof & GCEC & $25^{\circ} 51^{\prime} 13.40^{\prime \prime}$ & $28^{\circ} 22^{\prime} 01.19^{\prime \prime}$ & 9 & Lava & $306^{\circ} / 13^{\circ}$ \\
\hline Mooikloof & GCED & $25^{\circ} 51^{\prime} 11.78^{\prime \prime}$ & $28^{\circ} 22^{\prime} 05.15^{\prime \prime}$ & 11 & Lava & $306^{\circ} / 13^{\circ}$ \\
\hline Mooikloof & GCEE & $25^{\circ} 51^{\prime} 06.25^{\prime \prime}$ & $28^{\circ} 22^{\prime} 08.65^{\prime \prime}$ & 11 & Lava & $306^{\circ} / 13^{\circ}$ \\
\hline
\end{tabular}

\section{SAMPLING}

\subsection{Global selection of the sites}

In this study, we sampled 19 sites from the Hekpoort Formation (Fig. 4 and Table 1); about 9 to 13 plugs were collected from each site for a total of 198 oriented standard samples. We avoided as much as possible the top-hill outcrops in order to minimize the risk of sample's remagnetization due to lightning strikes that are common in the region. No backed and conglomerate field tests for palaeomagnetic stability (e.g. Van der Voo 1990) could be performed owing to the absence of post-Hekpoort intrusions (dykes or sills), and/or younger conglomerates that may contain clasts of the studied sedimentary Formation. However, we were able to carry out both fold and reversal tests.

Sampling was achieved by drilling individually oriented cores with a portable, handheld petrol drill. The orientation of the cores was measured in situ by both magnetic and sun compasses. Oriented cores were cut into $\sim 2 \mathrm{~cm}$ long samples for both magnetic mineralogy and palaeomagnetic measurements. The samples represent three main areas from west to east: the Potchefstroom syncline, the Wedela area and the Mooikloof area (Fig. 4). These areas, detailed in Sections 3.3-3.5, are almost the only one suitable outcrops for palaeomagnetic study of the Hekpoort Formation. Indeed, the majority of the area mapped as Hekpoort Formation corresponds either to agricultural fields or lava boulder strewn fields (Fig. 3a).

The Hekpoort Formation was only affected by lower greenschist facies metamorphism (e.g. Button 1973; Lenhardt et al. 2012; Humbert et al., in preparation; and see the next section) and this may indicate the potential of the studied rocks for a successful palaeomagnetic study. However, it should be kept in mind that several younger Bushveld-related intrusions occur in the eastern and southern part of Potchefstroom (e.g. Salminen et al. 2009) and could have possibly affected the Hekpoort Formation. Furthermore, large terrains of the Hekpoort Formation overlap with the distribution area of the Vredefort impact structure (Fig. 1). This structure had a significant impact on the palaeomagnetism on the rocks within its distribution area (e.g. Salminen et al. 2009). In summary, the magnetization of the Hekpoort Forma- tion is expected to be affected in part or wholly by the Bushveld Complex and the formation of the Vredefort impact structure around 2.55 and $2.23 \mathrm{Ga}$.

\subsection{Petrographic description of the sampled rocks}

Detailed petrography, including optical observations and electron microprobe measurements, of the Hekpoort rocks reveal that they were indeed submitted to low to moderate greenschist facies metamorphism; together with the rocks' 'long-term' metasomatic alteration, including silicification of the rocks and albitization of the plagioclase (Humbert et al., in preparation). The metamorphism is static and no evidence of any schistosity or foliation was observed in all the studied outcrops, or even in the whole Hekpoort Formation (e.g. Lenhardt et al. 2012). Yet, some primary minerals are still preserved (note that ferromagnetic grains will be discussed in Section 5.1): mostly the clinopyroxenes (mainly Mg-rich augite, together with diopside \pm pigeonite in some samples; Figs $3 \mathrm{~d}-$ g). Orthopyroxene (generally euhedral) were identified in several sites by normative calculation but are now fully pseudomorphosed in clinochlore (Fig. 3g). Plagioclases (labradorite) are present in the samples as phenocrysts (Fig. 3b), $0.5-1 \mathrm{~mm}$ euhedral grains (Fig. 3e), microliths (Fig. 3d) and skeletal crystals (Fig. 3f). However, the majority of them lost a huge portion of their $\mathrm{Ca}$ due to albitization and now exhibit compositions with less than 15 per cent of anorthite. The $\mathrm{Ca}$ was probably incorporated in different secondary minerals: calcite around the plagioclase (Fig. 3f), epidote (Fig. 3e) and, rarely, titanite. Microlith of Mg-rich hornblende is sometimes found in some samples, but never in abundances of more than a percent of the rocks. Other secondary minerals observed are actinolite, almost pure K-feldspars and quartz. The latter being the main mineral filling the amygdales (with clinochlore), but can be also found around ferromagnesian minerals (Fig. 3g).

Phenocrysts and euhedral primary minerals are assumed to be already crystallized before the extrusion of the lavas, and the other primary minerals during or just after extrusion. Only one site (PWD) shows plagioclase phenocrysts. While all other Hekpoort samples are showing aphanitic to hemicrystalline texture and are thus clearly 
lavas. The samples from the site PWD can be considered as to be intermediate between a basalt and a dolerite because they contain centimetre-sized plagioclase and are almost fully crystallized. On the other hand, the matrix contains amygdales and presents a microlitic texture more representative of basalts; in addition, skeletal plagioclase (Fig. 3f) characteristic of fast cooling, can be easily found in the PWD samples. We note that a shallow intrusion can possibly present such a texture, but we did not find any evidence that the rocks in site PWD are cross-cutting the other surrounding Hekpoort rocks. The rocks of this site are nonetheless regarded as belonging to the Hekpoort Formation in that they present the exact same geochemistry (Humbert et al., in preparation).

\subsection{Potchefstroom syncline}

This syncline is located in the Northwest Province on the western side of the town of Potchefstroom (Fig. 3a). This syncline corresponds to an asymmetrical regional scale fold, with a dip of $10^{\circ}$ or less along its western limb and a steeper dip, around $30^{\circ}-35^{\circ}$, along the eastern limb. Folding postdate the extrusion of the Hekpoort lavas, and was certainly related to the Vredefort impact structure. This syncline belongs to a regional surface exposure of the Hekpoort lavas in monocline or syncline structures, displayed along an arc at a distance between 55 and $63 \mathrm{~km}$ from the centre of the Vredefort dome (Fig. 1).

In this syncline, the Hekpoort Formation overlies the Timeball Hill Formation and is covered by sedimentary lithologies of the Dwaalheuwel and Strubenskop formations as witnessed by an outlier of these two formations in the central part of the syncline (Fig. 4a). This syncline provides a window through the whole preserved thickness of the Hekpoort Formation in the studied area. We observed single compound lava flows showing thicknesses of $9 \mathrm{~m}$ in average; the top flow being characterized of a thick layer $(50 \mathrm{~cm}$ to $1 \mathrm{~m}$ ) mainly composed of amygdales. Thin $20 \mathrm{~cm}$ to $1 \mathrm{~m}$ lava sheets, marked by $1-3 \mathrm{~cm}$ thick amygdales layer, can sometimes be observed inside the single compound lava flows.

Six sites (PWA to PWF; Table 1) were sampled in total. Site PWD, discussed previously, is located on the eastern limb and represents basal basaltic flows showing clinopyroxenes (augite and pigeonite) and randomly oriented phenocrysts of plagioclase (Fig. 3b). Sites PWA and PWF, from the lower half of the formation consist of slightly massive basalt either showing a microlitic texture with some macroscopically visible crystals, including plagioclase phenocrysts (Fig. 3b). These two sites cover around 50 and $15 \mathrm{~m}$ of stratigraphic thickness, respectively. Three sites represent the upper half of the Hekpoort Formation in the area. Sites PWB and PWC are pyroxenerich massive basaltic flows covered by highly weathered pyroclastites (not sampled for palaeomagnetism). The last site, PWE, from near the top of the formation correspond to several basaltic flows showing individual thicknesses of between 20 and $30 \mathrm{~cm}$.

\subsection{Wedela}

All geological units in this area, which is located in Gauteng Province, have been moderately tilted (between $20^{\circ}$ and $30^{\circ}$ ) toward the SSE, likely in response to the Vredefort impact event. Here, a total of eight sites were sampled in three different localities (Table 1): (1) the area around the Danie Theron Monument (DTH sites), (2) the area west of Wedela (ERA sites) and (3) a last site (DK) to the west (Fig. 3b) where near horizontal dipping aphanitic lava flows was drilled.
Sites DTH (3 in total) were sampled at different stratigraphic positions in the lower part of the Hekpoort Formation. From the bottom upward, these are: DTH-B, DTH-A and DTH-C. Sites DTH$\mathrm{B}$ and DTH-C consist of massive basaltic lavas with sporadic large amygdales (up to $20 \mathrm{~cm}$ ) mainly filled with quartz at both sites and also clinochlore at site DTH-C. Site DTH-A represents several individual lava flows.

We also sampled four other sites (ERA-A to ERA-D) west of Wedela, especially because that area includes a gentle fold which was covered by the sites ERA-A, ERA-B and ERA-C; which make it theoretically interesting for a fold test. Yet, the four ERA sites present either poor magnetic recording or inconsistent results (see Section 5.2.3.). In addition, obvious differences can be observed between the ERA sites samples and all other Hekpoort samples regarding the ferromagnetic grains s.l. carrier of the remanence, supposed to mainly be either pyrrhotite or greigite (see Section 5.1.).

Further studies on the Hekpoort rocks in this area, unfortunately done after the sampling and palaeomagnetic measurements, give an explanation to such phenomenon: supercooling or the lava together with devitrification (Humbert et al., in preparation). This ERA area is peculiar as it the only part of the Hekpoort Formation composed of variolitic flows up to $3 \mathrm{~m}$ thickness. Each flow presents a basal zone with prominent an upper variolitic zone, rich in magmatic related spheroids, namely variolites (Fig. 3h), and a lower zone sometimes showing cooling joints and almost totally devoid in variolites. Individual variolites are well-rounded spheroids of up to $30 \mathrm{~cm}$ in diameter, but usually smaller $(1-6 \mathrm{~cm})$, and are only composed of acicular clinopyroxene needles (with a width of $1 \mu \mathrm{m}$ ) radial core to rim. The two layers are also rich (30-70 per cent of the rock) in skeletal clinopyroxene phenocrysts showing length up to $4 \mathrm{~cm}$ and randomly oriented in the whole rocks; they are easily distinguishable inside the variolites by colour contrast in Fig. 3(h).

All the rocks in the ERA area are related to a supercooling. This cooling provided first skeletal clinopyroxenes, rich in $\mathrm{Al}_{2} \mathrm{O}_{3}$ (up to $12 \mathrm{wt} \%$; Humbert et al., in preparation) marking the fast cooling, and which were formed at the same time as amygdales. In a second time, the acicular clinopyroxene, and thus variolites were formed, provoking a diffusion of several elements that can hardly get inside the CPX lattice. This diffusion is only possible above the temperature of glass transition (Gardner et al. 2014). We yet still not know why the variolites only formed at the upper part of the flows. The last step regards the groundmass around the variolites and happened after the cooling: this groundmass has been incompletely crystallized by devitrification process (Hanski 1993). It is thought that most ferromagnetic grains were formed during this step, and thus not before or during the emission of the lavas. We avoided to drill into the variolites for the palaeomagnetic study.

\subsection{Mooikloof}

This area is located west of Pretoria (Figs 1 and 4), where rocks the upper Transvaal Basin (Pretoria Group) dips to the NE below the Rustenburg Layered Suite, part of the Bushveld Complex. Here, the Hekpoort Formation is up to $540 \mathrm{~m}$ thick with a consistent $13^{\circ}$ dip angle. The Hekpoort Formation is developed on top of the Boshoek Formation and is overlain by the Strubenskop Formation.

Five sites were sampled: GCE-A to GCE-E. They are all massive flows of basalts rich in plagioclase and pyroxenes. The one exception is GCE-A, which represents a pyroclastite (Fig. 3g). This site is located in the basal part of the Hekpoort Formation, while other sites are from progressively higher stratigraphic levels (GCE-C, GCE-D, GCE-E and GCE-B). 


\section{METHODOLOGY}

\subsection{Magnetic mineralogy}

The magnetic mineralogy of 17 samples was characterized by thermal demagnetization of the isothermal remanent magnetization (IRM) following the protocol of Lowrie (1990), and by the temperature variation of susceptibility of samples. During the IRM procedure, various coercivity fractions of magnetic minerals are remagnetized in successively smaller fields (i.e. 1200, 500 and $100 \mathrm{mT}$ ) along one of three orthogonal directions or axes, before being thermally demagnetized. Low-coercivity minerals like magnetite are mainly remagnetized along the $100 \mathrm{mT}$ low-coercivity axis. Ferrimagnetic iron sulphides like greigite or pyrrhotite will be remagnetized along the $500 \mathrm{mT}$ intermediate coercivity axis. Highcoercivity minerals, like haematite can then be identified along the $1200 \mathrm{mT}$ axis. Stepwise thermal demagnetization of IRM was conducted up to $580^{\circ} \mathrm{C}$ in $20-50{ }^{\circ} \mathrm{C}$ intervals. Smaller intervals were applied around the known Curie temperature of common magnetic minerals (i.e. before $115^{\circ} \mathrm{C}$ for goethite, around $330{ }^{\circ} \mathrm{C}$ for greigite and pyrrhotite, and before $580^{\circ} \mathrm{C}$ for magnetite) (e.g. Lowrie 1990 ; Tarling \& Hrouda 1993). Remanent magnetization was measured with an AGICO JR-6 spinner magnetometer.

The temperature variation of magnetic susceptibility of the samples was measured using the KLY-4S Kappabridge and nonmagnetic furnace AGICO CS-3 at the University of Cergy-Pontoise (France). Measured data were processed using the computer code CUREVAL (AGICO, Inc.). Measurements, consisting of heating and cooling, were done on about $100 \mathrm{mg}$ of powder for each sample. We proceeded by steps on the same powder for each sample, that is, heating from room temperature up to a threshold temperature (progressively increased as follow 250, 350, 450, 550, 650 and $700^{\circ} \mathrm{C}$ ) and then cooling back to the room temperature. The susceptibility variation was measured around every three minutes; the heating and cooling rates were around $1{ }^{\circ} \mathrm{C}$ per minute.

Upon heating, ferromagnetic susceptibility is expected to decrease as temperature converge to Curie temperature, which marks the transition to paramagnetism, while susceptibility is expected to show a reversible increase during cooling. Mineral phases can, however, alter partially or completely during the heating (e.g. goethite, maghemite and clay minerals) leading to the crystallization of new phases (e.g. haematite) either during the heating or cooling.

\subsection{Thermogravimetric and differential thermal analysis}

Thermogravimetric (TG) analysis is used to follow the sample weight variation during heating and differential thermal analysis (DTA) to follow the evolution of the temperature difference between the studied sample and an inert control body also during the heating. The overlay of TG and DTA curves shows the changes in chemical composition (weight loss on TG coupled with an exo- or endothermic peak on DTA) and in the crystal structure (only DTA peak, no associated weight loss) of the sample.

The DTA-TG analysis were carried out simultaneously using a STA 449 F1 Jupiter analyzer (NETZSCH). The temperature measurement was performed with a type $\mathrm{S}$ thermocouple (platinum rhodium-10 percent per platinum). The sample was taken in an alumina crucible and heated from room temperature to $700{ }^{\circ} \mathrm{C}$ at a heating rate of $11^{\circ} \mathrm{C} \mathrm{min} \mathrm{m}^{-1}$ in order to operate in same conditions as for CS3 thermomagnetic measurements. The test was conducted under dynamic nitrogen atmosphere $\left(50 \mathrm{~mL} \mathrm{~min}{ }^{-1}\right)$. An empty alumina crucible was used as the reference material.
All the tests were performed by using approximately $120 \mathrm{mg}$ of sample.

\subsection{Palaeomagnetism}

Palaeomagnetic samples were subjected to stepwise demagnetization. The measurements were conducted in laboratories at the University of Johannesburg (South Africa) and at the Academia Sinica (Taiwan). The University of Johannesburg is equipped with a vertical 2 G Enterprises DC-4 K superconducting rock magnetometer with automated sample changer (Kirschvink et al. 2008). Following a measurement of the NRM and low-field-strength alternating field (AF) pre-treatment in four steps up to $10 \mathrm{mT}$, the sample were thermally demagnetized. Thermal demagnetization was achieved in an ASC TD48-SC shielded furnace at 15 decreasing intervals from $100^{\circ} \mathrm{C}$ up to $580^{\circ} \mathrm{C}$ or until magnetization dropped below the noise level of the magnetometer's sample handler (below $1 \times 10^{-7} \mathrm{~A} \mathrm{~m}^{-1}$ ). At the Academia Sinica, the measurements were carried out using a 2 G SQUID magnetometer. Thermal demagnetization was achieved in 17 steps from 25 to $600^{\circ} \mathrm{C}$.

Magnetic components for all samples were identified and quantified via least-squares principal component analysis (Kirschvink 1980). These calculations, together with all subsequent statistical analyses, utilized both the software Palaeomag (Jones 2002) and Palaeomac V6.5.24 (Cogné 2003). Linear fits were included in subsequent analyses if they had a mean angle deviation $\leq 10^{\circ}$. One to four components of magnetization have been distinguished per sample. Fisher statistics was used for calculating average magnetization components per site or group of sites. Virtual geographic poles or VGPs were calculated for each component based on site coordinates and assuming both a geocentric axial-dipole field and a stable Earth radius throughout geological time.

\section{RESULTS}

\subsection{Magnetic mineralogy}

We conducted a three-axes thermal demagnetization of the IRM on a set of 17 samples (Fig. 5). All sites were represented by at least one sample. Slight decreases in magnetization at and before $115^{\circ} \mathrm{C}$ can be explained by small quantities of goethite. This mineral can present an extremely high coercivity (Dekkers 1989), and thus, it is commonly not fully remagnetized by a $1200 \mathrm{mT}$ field allowing it to retain a natural magnetization that can be expressed along the highcoercivity axis. The presence of haematite can be ruled out in our samples, since they are almost totally demagnetized around $580^{\circ} \mathrm{C}$. Some samples are demagnetized slightly below $580^{\circ} \mathrm{C}$ which can be explained but the fact that magnetite contains a small proportion in titanium. Titanomagnetite, which are common in igneous rocks, indeed present a Curie temperature lower than $580^{\circ} \mathrm{C}$, variable following the content in titanium (e.g. Dunlop \& Özdemir 1997). The content of $\mathrm{TiO}_{2}$ in the Hekpoort lavas is relatively constant, between 0.5 and $0.7 \mathrm{wt} \%$ (Humbert et al., in preparation).

All samples display a drop in magnetization around $325^{\circ} \mathrm{C}$ (Fig. 5) along the low and medium coercivity axes. Maghemite could be responsible for the decrease in magnetization around $325^{\circ} \mathrm{C}$. This mineral is characterized by a Curie temperatures of $645^{\circ} \mathrm{C}$ with a low coercivity and is rather expected to be magnetized along the $100 \mathrm{mT}$ (Özdemir \& Banerjee 1984). However, because of its metastability, the maghemite is inverted into haematite during the heating at variable temperature starting at $250^{\circ} \mathrm{C}$ (Dunlop 

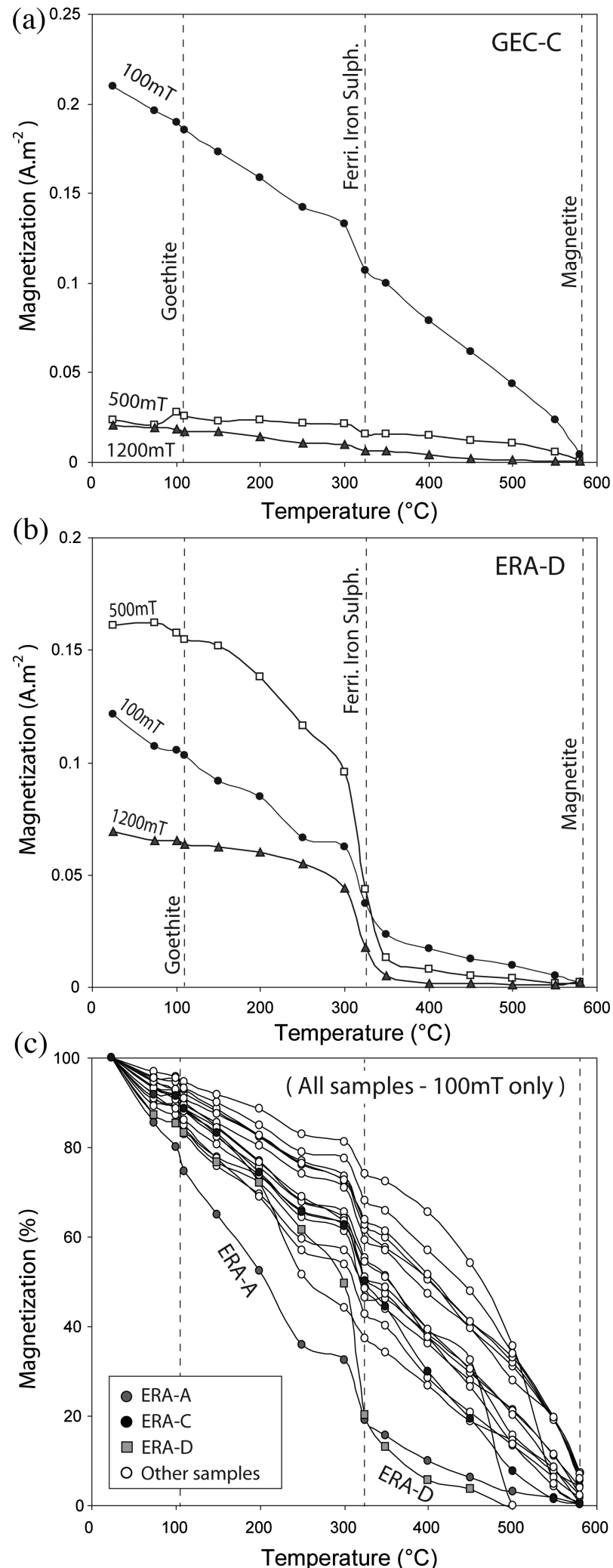

Figure 5. Magnetic mineralogy determination by thermal demagnetization of the IRM. (a) Example of thermal demagnetization curves for high $(1200 \mathrm{mT})$, medium $(500 \mathrm{mT})$ and low $(100 \mathrm{mT})$ coercivity components in a sample rich in magnetite. (b) Same as (a) for a sample rich in ferrimagnetic iron sulphide. (c) $100 \mathrm{mT}$ curves for all the 17 measured samples after normalization to the natural remanent magnetization (NRM).
\& Özdemir 1997). The decrease in magnetization around $325^{\circ} \mathrm{C}$ (Fig. 5c) is also in agreement with the expected Curie temperature of ferrimagnetic iron sulphide. The presence of pyrite in several of the Hekpoort samples suggests that other iron sulphides species might also be present.

In addition to the loss of magnetization at $325^{\circ} \mathrm{C}$, all of our samples (with the exception of two from sites ERA-A and ERAD) display either progressive linear demagnetization (observed on samples where 50 per cent of the magnetization is lost between 300 and $360^{\circ} \mathrm{C}$ ) or a curved demagnetization, with a concave shape (observed on samples where more than 50 per cent of the magnetization subsist after $380^{\circ} \mathrm{C}$ ). Both of these behaviour types are attributed to magnetite. The variation of the shape of the demagnetization curve indicates a distributed unblocking temperatures spectrum especially since for small, or near equidimensional, grains of magnetite (Dunlop \& Özdemir 1997). So, this can be interpreted as follows: the curves showing magnetization loss of half quantity between 300 and $360^{\circ} \mathrm{C}$ are typical of single-domain (SD) magnetite, while the magnetization loss mainly above $360^{\circ} \mathrm{C}$ suggest the presence of some richest multidomain magnetite samples. A link can, however, be established for some, but not all, samples, between the increasing degree of crystallinity of the lavas (i.e. an increasing primary crystals/glass ratio) and size of magnetite grains. All in all, magnetite appears to dominate the magnetization signal (Fig. 5a and c) of most samples. Only the variolitic samples (ERA sites) display ferrimagnetic iron sulphides as other magnetic carriers (Fig. 5b and c), while both magnetite and ferrimagnetic iron sulphides appear to be present in significant quantities in a sample from site ERAC. Other studies already observed pyrrhotite grains in variolitic or spherulitic mafic rocks, either in nucleus inside the spherulites or dispersed throughout the glassy matrix (e.g. Monecke et al. 2004; Gardner et al. 2014).

In order to confirm the lack of mineralogical transformations during the heating as of $350{ }^{\circ} \mathrm{C}$ as suggested by stepwise thermal demagnetization, we also measured the variation of magnetic susceptibility with stepwise temperature (Fig. 6). On each selected sample, the heating-cooling curves are superimposable up to $550^{\circ} \mathrm{C}$, and no drop of susceptibility was observed; such drop is characteristic of the inversion of maghemite to haematite due to the higher susceptibility of maghemite relatively to haematite. All of this means that such inversion of maghemite to haematite is not possible below this temperature. In addition, there is no clear Curie temperature above $600^{\circ} \mathrm{C}$. During cooling stage, the magnetic susceptibility curves are not longer reversible and the maximum drop of susceptibility appears below $580^{\circ} \mathrm{C}$. These results confirm that magnetite is the main susceptibility carrier for all samples and show that maghemite can be ruled out of them.

Some samples exhibit higher heating than cooling curve in the temperature range of $560-700^{\circ} \mathrm{C}$. This is indicative that a mineral phase was created at a temperature above $550{ }^{\circ} \mathrm{C}$ because this phenomenon only appear at the $650{ }^{\circ} \mathrm{C}$ step. The fact that the susceptibility increase between 580 and $550{ }^{\circ} \mathrm{C}$ strongly suggest that this new phase is a magnetite. The step at $700^{\circ} \mathrm{C}$ done in one sample (DTH-B) reveals that, on the one hand, this newly magnetite is stable, and, on the other hand, more magnetite is created. The origin of such secondary magnetite might be explained by a destabilization of a paramagnetic silicate phase (e.g. clay mineral) facing increasing temperature. It should not be forgotten that, unlike remanence, magnetic susceptibility summarizes the contribution of all grains in the samples. 


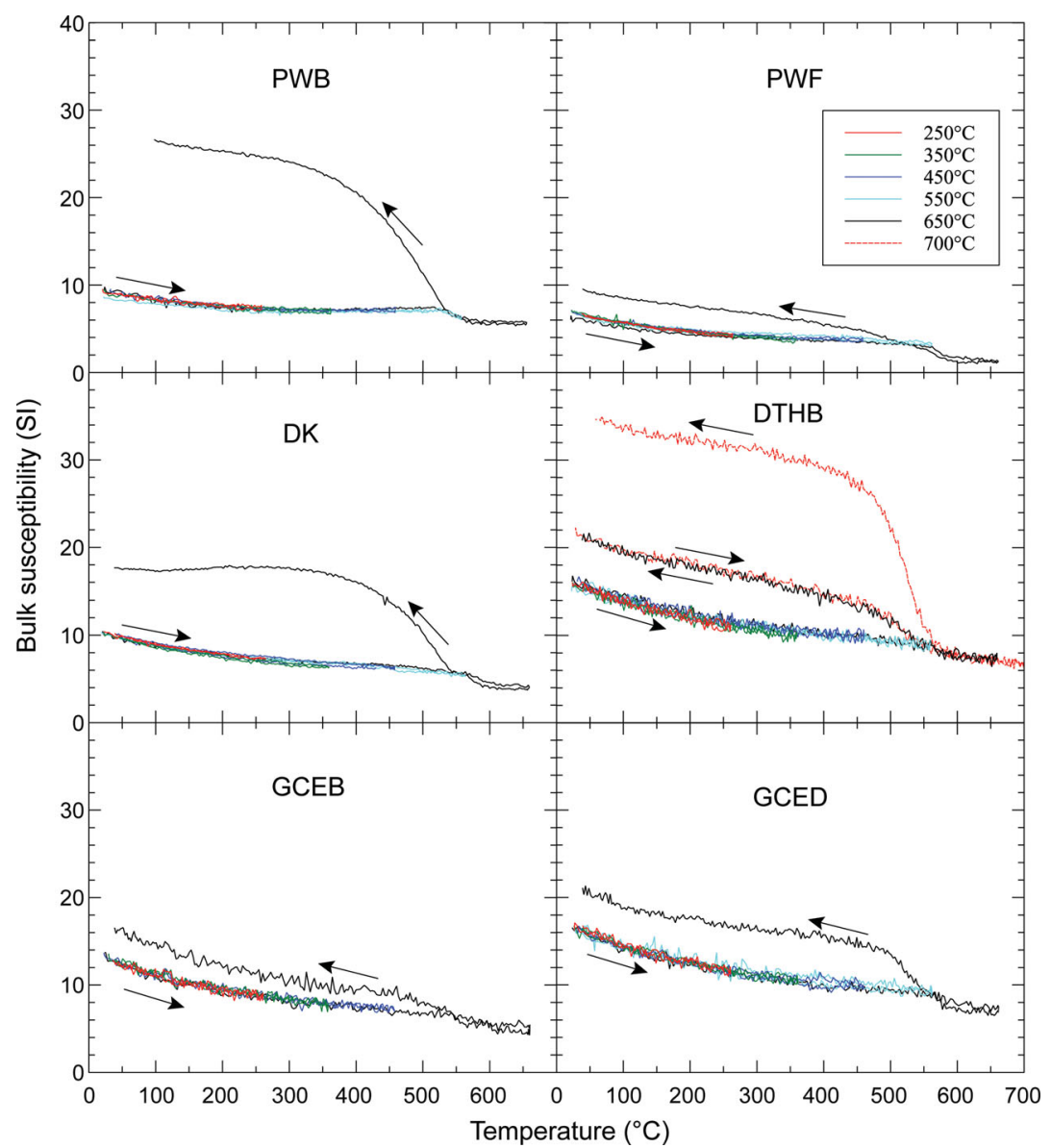

Figure 6. Variation of bulk magnetic susceptibility versus temperature two samples from each group of sites. For all samples, the cooling curve starts to be different from the eating curve at the $650{ }^{\circ} \mathrm{C}$ step.

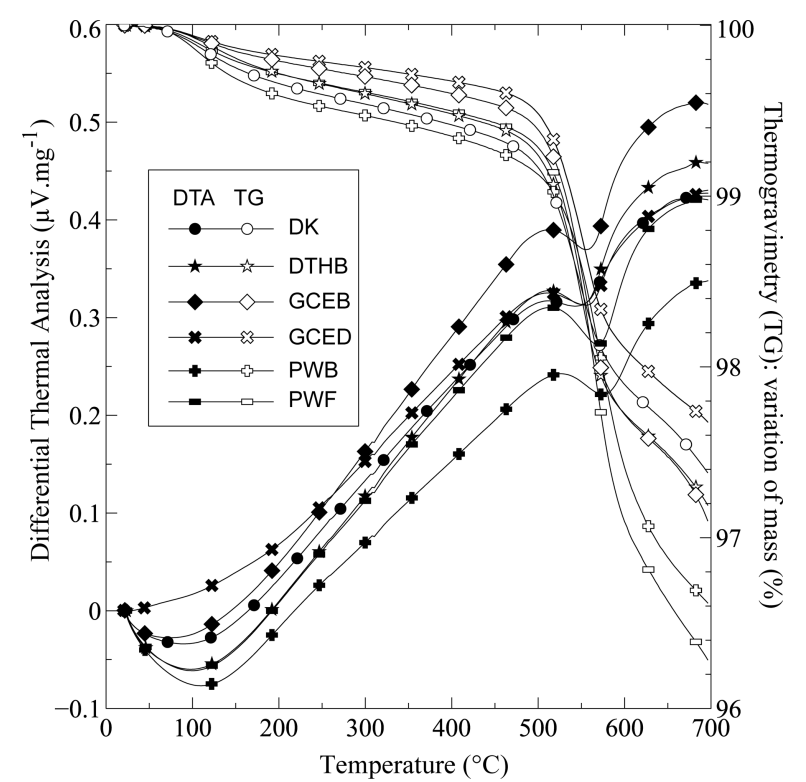

Figure 7. Differential thermal and thermogravimetric (TG) analysis done on the same samples presented in Fig. 6.

Finally, the TG and DTA curves, done of the same samples, are in good agreement with the previous result. One can see that all samples show roughly the same behaviour (Fig. 7). The TG curves are generally characterized by two distinct slope measure the variation of masse upon heating. Up to $500^{\circ} \mathrm{C}$, one can observe a slight linear decrease associated to the dehydration of the samples. At $550^{\circ} \mathrm{C}$ and temperature just above, the DTA curves indicate a clear endothermic peak observed in all samples. This peak is characteristic of magnetite or titanomagnetite (Vollstädt 1968; Mária 2011) and marks the transition from ferrimagnetism to paramagnetism of (titano-) magnetite. The DTA curves, thus provide complementary information about Curie point, which is measured between 555 and $580^{\circ} \mathrm{C}$.

\subsection{Demagnetization}

Individual samples generally responded in one of three ways to demagnetization (Fig. 8). Some samples displayed no to very low remanence during demagnetization, others were dominated by single magnetic components, while a third group of samples were easily characterized by between two to a maximum of four magnetic components. Five different component directions could be identified in our samples from both thermal and AF demagnetizations. We labelled these from HKA to HKE, following the level at which they unblocked. HKA has the highest unblocking characteristics and HKE the lowest.

Samples from the ERA-A and ERA-B sites and about 30 per cent of samples from sites DTH-A and DTH-C appear to be weakly magnetized, with NRM's intensity below $5 \times 10^{-7} \mathrm{~A} \mathrm{~m}^{-1}$ ). These samples were generally totally demagnetized (between 300 and $450{ }^{\circ} \mathrm{C}$ ). The alteration of ferromagnetic phases during weathering or an 


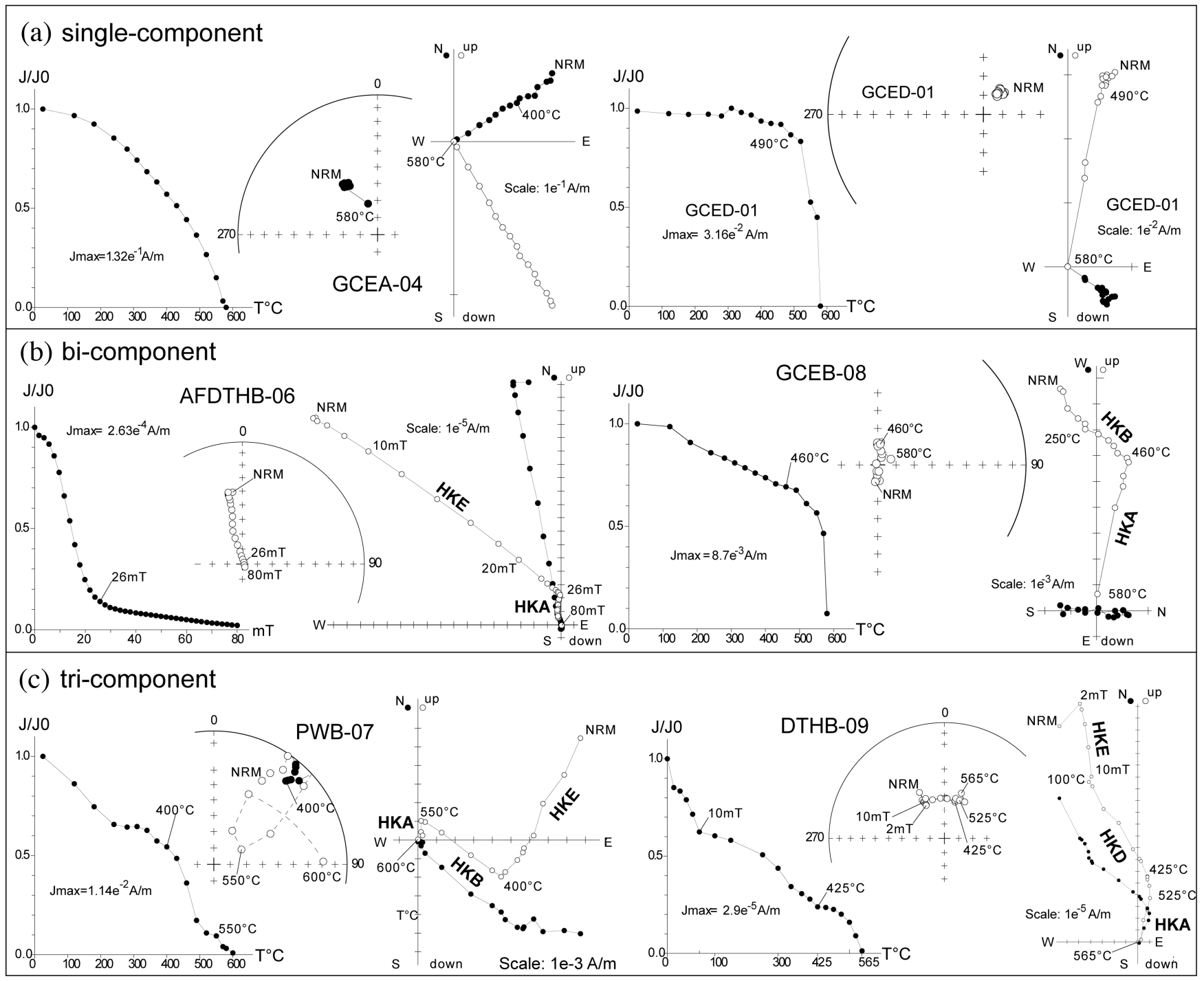

Figure 8. Representative sample behaviour during demagnetization for essentially. (a) Some samples did not respond well to demagnetization and show only one component. These samples record high-coercivity components with random orientation. One cannot that the sample GCED-01 shows a high unblocking temperature certainly due to the adverse effects of lightning strikes, while the sample GCED-01 presents a progressive demagnetization from the NRM. (b) and (c) Typical Hekpoort samples behaviours during full AF demagnetization (sample AFDTHB-06), full thermal demagnetization (samples GCEB-08 and PWB-07) and thermal demagnetization after an AF 'cleaning' (sample DTHB-09), showing 2-3 components. Note that the HKB component is starting at $250{ }^{\circ} \mathrm{C}$ in sample GCEB-08 (before data are misaligned unlike it looks on the graphic). Solid symbols = horizontal plane, open symbols $=\mathrm{W}-\mathrm{E}$ and vertical plane. $\mathrm{NRM}=$ natural remanent magnetization.

initial low content of such phases would explain this behaviour. These sites will not be further discussed in this paper.

Single-component samples are dominated by unique uniform ('randomly') distributed components. Around 25 per cent of samples show this behaviour. It was mainly encountered in the samples from ERA sites (40-50 per cent of the samples), and in nearly all (80-100 per cent) of the samples of the DK, GCE-A and PWD sites. For the main part these samples show high blocking temperature, around $490^{\circ} \mathrm{C}$ (e.g. GCED-01; Fig. 8a). The remanence in such cases can be reasonably linked to lightning induced magnetizations. Some other samples present no specific blocking temperature displaying humped or constantly decreasing patterns on the $J / J_{\max }$ diagrams whatever for thermal or AF demagnetization (e.g. sample GCEA-04; Fig. 8a), which is less characteristic of lightning induced magnetizations. Such enigmatic behaviour was also observed by several other authors in similar age rocks (e.g. de Kock et al. 2009b).
Two-component samples are quite common, and this behaviour is revealed during both thermal and AF demagnetizations. The first component is often parallel to the present local geomagnetic field (clearly shown by 40 percent of the samples). The second component usually has a high blocking temperature of around 450 $560{ }^{\circ} \mathrm{C}$ (e.g. sample GCEB-06; Fig. 8b), or is revealed between 40 and $70 \mathrm{mT}$. The 'three-components' and 'four-components' samples show the same high component magnetization than the 'twocomponents' samples. They stand out from 'two-components' sample by presenting one or two additional components at higher levels of demagnetization.

\subsubsection{Potchefstroom syncline}

Among the six sampled sites located in the Potchefstroom syncline, five responded well to demagnetization (Fig. 9). Site PWD yielded only single, randomly magnetization vectors (Fig. $10 ; \alpha_{95}=39.5^{\circ}$ ). 


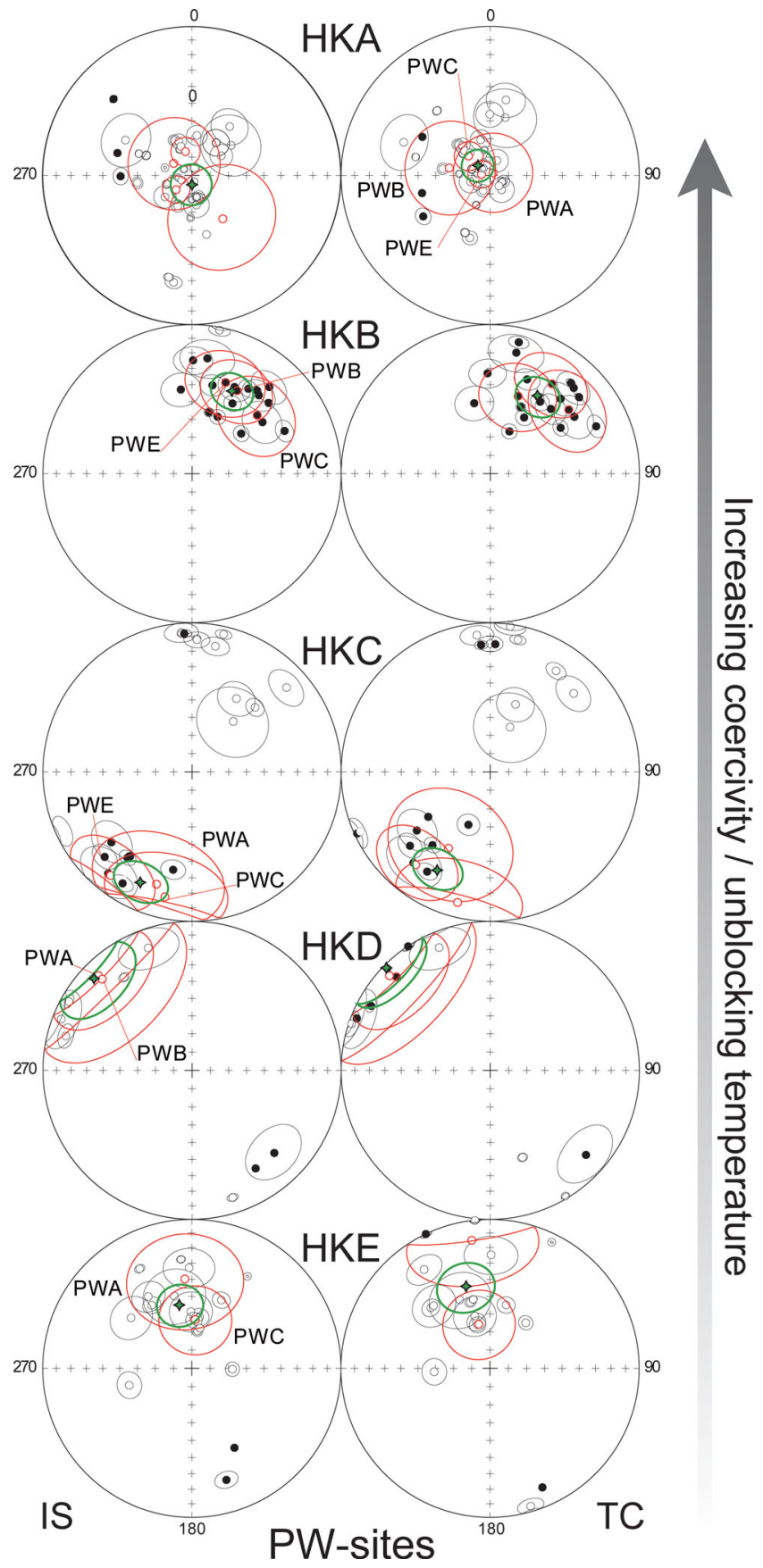

Figure 9. Equal-area plots of remanence components showing HKA to HKE components from the PW sites. The red ellipse corresponds to the 95 per cent confidence ellipses of the sites containing at least four samples showing one component; the green ellipses are the 95 per cent confidence ellipses for all the samples. IS $=$ in situ and TC $=$ tilt corrected.

We attribute these to lightening. All but three samples from the site PWF display the same behaviour. The other samples and sites yielded two to four magnetic components.

The first component (HKE) is identified during initial demagnetization steps as being northerly with negative inclination (Table 2). The components are totally demagnetized after $10 \mathrm{mT}$ in those samples submitted to the AF pre-treatment, and is generally demagnetized around $300^{\circ} \mathrm{C}$ in other samples. HKE was identified in 20 samples $\left(\alpha_{95}=12.1^{\circ}\right)$.

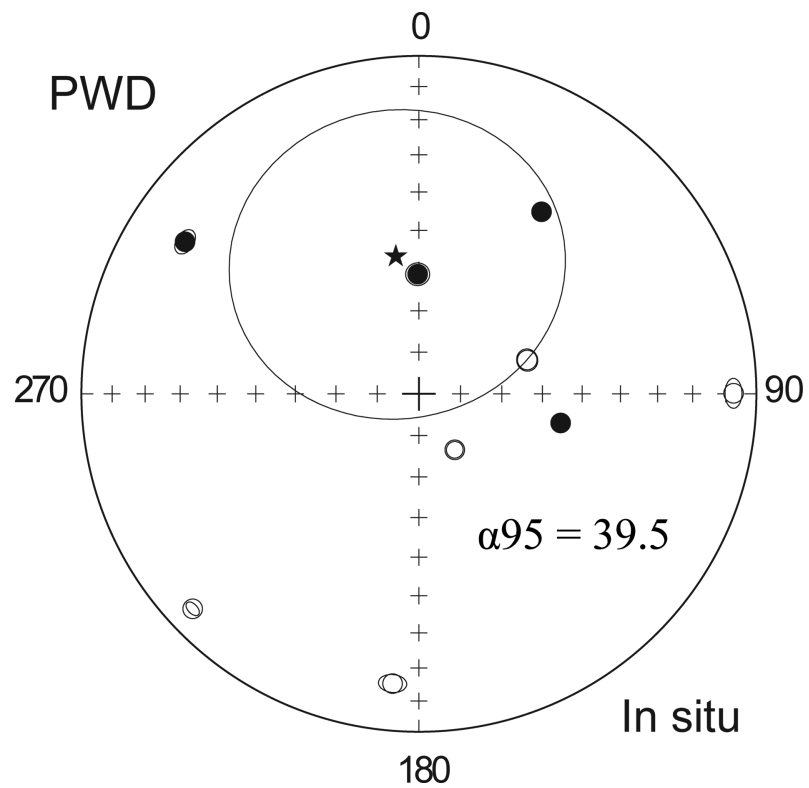

Figure 10. Equal-area plots of remanence components from sites showing lightening induced remanence (PWD).

The two next magnetic components are of low inclination and display either an SW+ (i.e. downward) or a NW-(i.e. upward) trend. They occur over a generally similar, but large range of temperatures and AF values, and are never present together within the same sample. We designate the SW+ components as HWC and NWcomponents as HWD. Component HKC is recorded by 18 samples in a range from 120 to $400{ }^{\circ} \mathrm{C}$. Component HKD is recorded by nine samples, all from the lower part of site PWA and samples from site PWB. It generally unblocks in between 120 and $370^{\circ} \mathrm{C}$, but in for half of the samples persists up to $400^{\circ} \mathrm{C}$. Most of these four components are well clustered, with $\alpha_{95}$ values below $=15^{\circ}$ (except for HKD in which $\alpha_{95}=17.2^{\circ}$ ), and all with a better clustering in the in situ configuration.

In 18 samples, the removal of HKE, HKD and HKC components is followed by the demagnetization of a component in the temperature range between $400{ }^{\circ} \mathrm{C}$ up to $550^{\circ} \mathrm{C}$. HKB components are northeast with positive inclination (i.e. downward) (Fig. 9). In one sample, HKB was the last component removed as a demagnetization trajectory towards the origin, in all other samples it is present as a demagnetization trajectory that miss the origin, revealing the presence of a higher stability component.

The higher stability component is labelled HKA, and is isolated during both thermal and AF demagnetizations at levels higher than $520^{\circ} \mathrm{C}$ and $60 \mathrm{mT}$, respectively. HKA was readily identifiable as clusters toward the vertical direction of the upper hemisphere in the majority of samples (Fig. 9), with a better cluster in tilt corrected (TC) configuration $\left(\alpha_{95}=8^{\circ}\right)$. Three samples coming for the highest part of the site PWA show a downward inclination (i.e. in the lower hemisphere). There is some scatter in the direction of the components we designate as HKA, but we feel justified in their inclusion given a match in lower stability components among samples.

\subsubsection{Mooikloof}

This area, which includes five sites, yielded the same five groups of components identified in the PW-sites (Fig. 11 and Table 1). Site GCE-A also presents single-component vectors characteristic of lightening induced remanent magnetization. The other GCE 
Table 2. Summary of least-squares component directions and component means for the Hekpoort Formation.

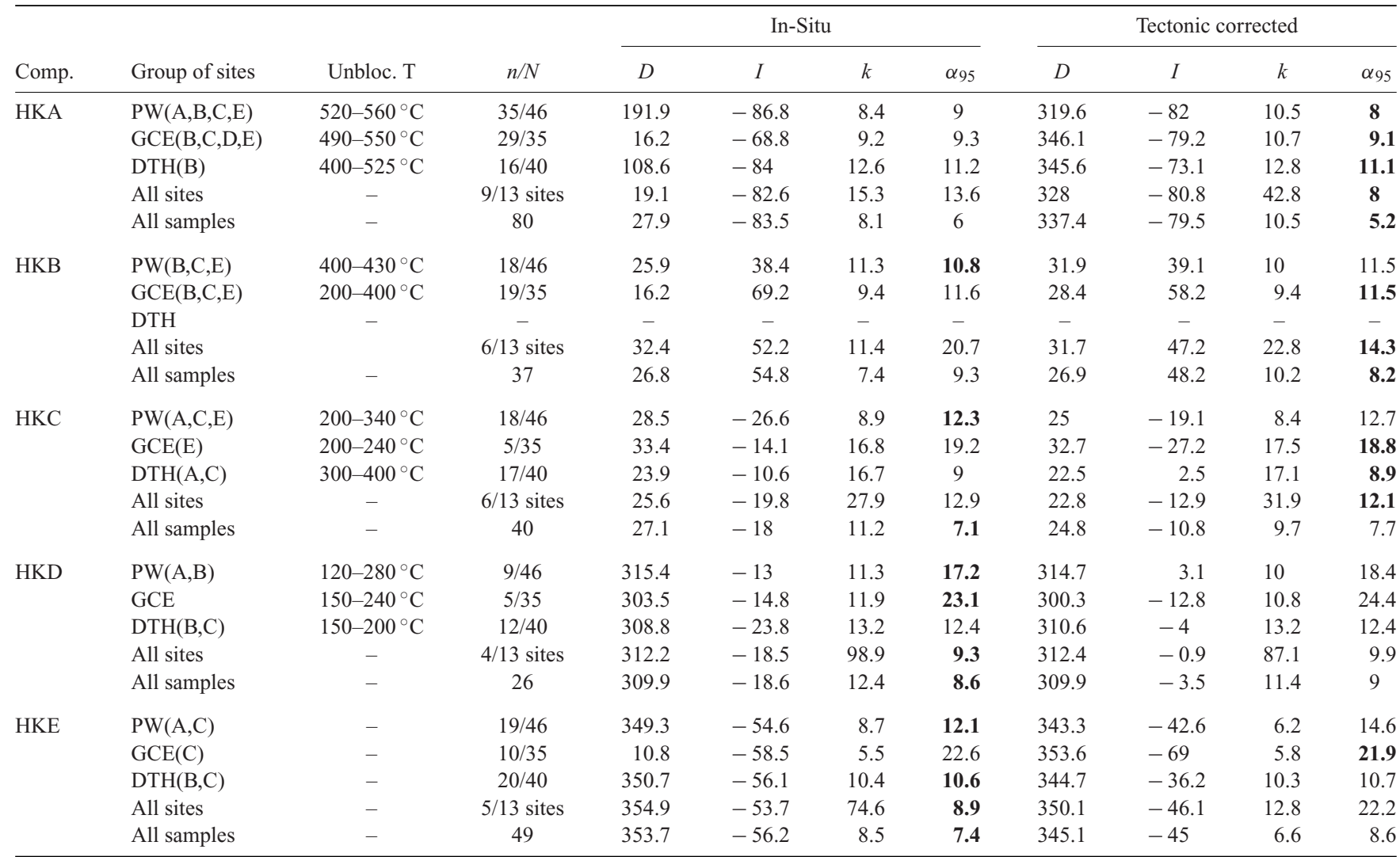

Notes: The PW group includes sites PWA to PWF (excluding PWD), the GCE group, sites GCE-B to GCE-E and the DTH group, sites DTH-A, DTH-B, DTH-C and DK. The sites PWD, GCE-A and all the ERA sites either showing lightening induced magnetization or magnetization linked to none primary ferromagnetic grains (see the text for more explanations) are not included here. $n / N=$ number of samples included/number of samples not excluded. Unbloc. $\mathrm{T} .=$ range of unblocking temperature in degrees Celsius, $D=$ mean declination in degrees, $I=$ mean inclination in degrees, $k=$ Fisher's precision parameter, $\alpha_{95}=$ radius of 95 per cent confidence cone. Bold $\alpha_{95}$ values highlight the best confidence cone between in-situ and tectonic corrected for each group of sites.

sites present again low number of single-component vectors (1-3 samples). Note that no sample from the GCE sites was submitted to any AF demagnetization.

Twenty-nine samples coming from all GCE sites present the HKA component, which is again defined by a northeasterly upward cluster toward the vertical axis (Fig. 11) and presenting a better cluster in the TC configuration $\left(\alpha_{95}=9.1^{\circ}\right)$. These components have an unblocking temperature above $520^{\circ} \mathrm{C}$, and all display linear trajectories towards the origin. Two samples present a southwesterly downward component. The HKB trend is represented by 19 samples either as NE+ (14 samples) or SW- 5 samples) orientations $\left(\alpha_{95}=11.5^{\circ}\right)$, both with moderate inclinations. The range of unblocking temperature is generally above $400{ }^{\circ} \mathrm{C}$ for the downward components, and significantly lower, slightly above $200^{\circ} \mathrm{C}$, for the upward ones. However, they all present a high maximal temperature of demagnetization, at least above $400^{\circ} \mathrm{C}$ and often close or higher than $500^{\circ} \mathrm{C}$. Two samples, belonging to sites GCE-C and GCE-E, presents the SW- upward component and then the NE+ downward component at higher levels of demagnetization. This suggests a dual polarity magnetic overprint. Four samples have the HKB components as the highest stability component, all others also display HKA vectors at higher demagnetization levels.

Unlike the HKC and HKD trends of the PW sites, those trends are here represented by a limited amount of samples from all the GCE sites (Fig. 11), which can explain the poor cluster for each component $\left(\alpha_{95}\right.$, respectively, equal to $18.8^{\circ}$ and $\left.23.1^{\circ}\right)$. The unblocking temperature of the two components ranges between 180 and $370^{\circ} \mathrm{C}$. One sample from site GCE-B yielded both components, with unblocking temperatures of 180 and $310^{\circ} \mathrm{C}$, respectively, for HKD and HKC. No sample has either HKC or HKD as the highest stability component. Finally, a total of 10 samples, among GCE sites, clearly present the low-coercivity component HKE, characterized by an unblocking temperature of $50^{\circ} \mathrm{C}$, and being generally demagnetized below $300^{\circ} \mathrm{C}$.

\subsubsection{Wedela}

This area is containing eight sites but several of them were showing results complicated to interpret or inappropriate to characterized palaeopoles. First, the majority of the samples from the sites ERAA and ERA-B show very low magnetizations making these two sites unsuitable for palaeomagnetic investigation. Secondly, most samples of site DK present lightening induced remanence marked by randomly oriented single-component vectors. Several samples from the four ERA sites are also showing this behaviour. Much more troublesome, however, is the observation that the ERA sites are characterized by very scattered results even after discarding all the samples presenting obvious conflicting issues. Samples generally present two components: one 'main' component with low unblocking behaviour $\left(115-150^{\circ} \mathrm{C}\right)$ and generally totally demagnetized after $340-370^{\circ} \mathrm{C}$, and a very unstable component removed by AF pre-treatment. This is certainly related to the fact that remanent grains are not primary in those rocks (see Section 3.4). Even samples drilled at relative close distance to each other are exhibiting 


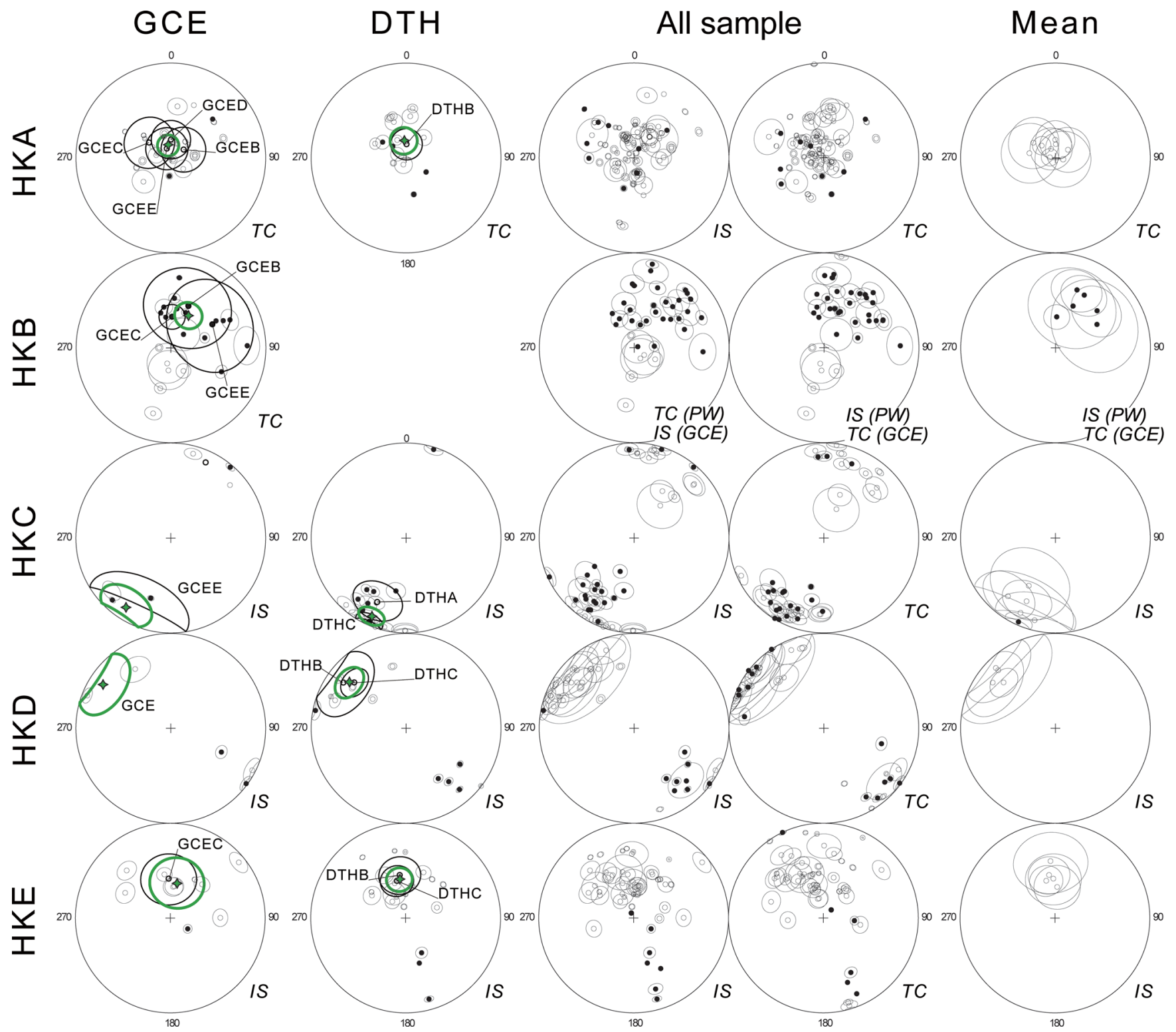

Figure 11. Equal-area plots of remanent components, showing HKA to HKE components from the GCE and DTH sites (left-hand side). The global results for each component, including the mean component direction for all samples (PW + GCE + DTH sites) presenting the component and associated 95 per cent confidence ellipse are represented in the fourth and fifth columns. The last column represents the same average based this time on the mean component direction of each site (if the component is present in at least one sample of the site). We represent either the in situ (IS) or the tilt corrected (TC) data according to the best cluster of vectors we obtained for each component. We choose to let both types of equal-area plot in the fourth and fifth columns part to allow the reader to graphically compare the two categories.

vectors with relatively different orientation ( $\alpha_{95} \approx 32^{\circ}$ in both cases) and only for half of the samples. Hence, we decided to discard the results from all the ERA sites.

Samples from the DTH sites and the three 'none single component' samples from site DK, present four different trends which fit with the ones identified in both the PW and GCE sites. The HKB component was not identified here. Sixteen samples, mostly from site DTH-B, show the HKA trend, including two downward components ('TC' $\alpha_{95}=11.1^{\circ}$ ). The HKC trend is represented by 17 samples, proportionally divided between the sites DTH-A and DTH-C $\left(\alpha_{95}=8.9^{\circ}\right)$. Showing unblocking temperatures between 300 and $400{ }^{\circ} \mathrm{C}$, this group of components is the highest coercivity one of the two sites. Twelve samples from two sites present the HKD component $\left(\alpha_{95}=12.4^{\circ}\right)$ marked by unblocking temperature between $150-200^{\circ} \mathrm{C}$. Site DTH-B with northwestern upward components and DTH-C with southeastern downward components, both with a shallow dip. However, we cannot exclude that they may correspond to two different events as the samples from site DTH-C present this component as the highest coercivity vector, and samples from the DTH-B site as the second one after HKA. Finally, 23 samples show the HKE trends which is almost always demagnetized below $200{ }^{\circ} \mathrm{C}$.

In summary, at the first order, the DTH sites have a bimodal behaviour. One site (DTH-B) present HKA, HKD (half of the samples) HKE components, and the two other sites (DTH-A and DTH-C) show HKC ( 75 per cent of the samples) or HKD ( 25 per cent of the samples) as primary component, then HKE. Such difference of behaviour can be also related to the relatively low magnetization of the sites DTH-A and DTH-C that was completely demagnetized at temperature between 450 and $500{ }^{\circ} \mathrm{C}$. 


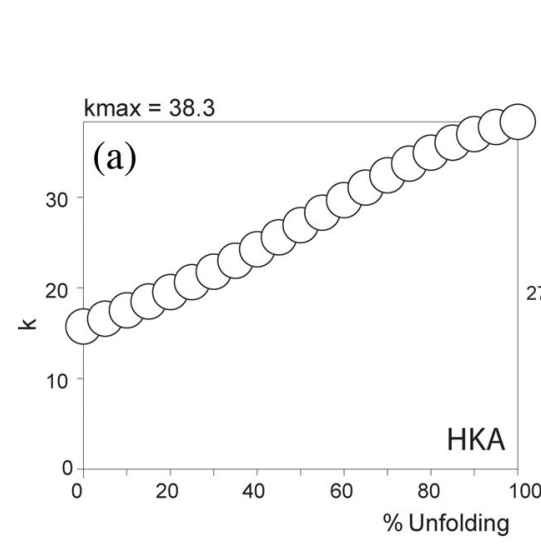

Fold test

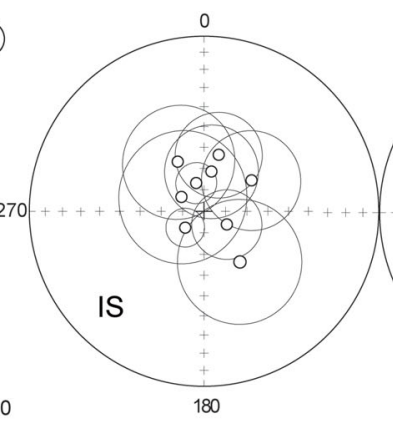

\begin{tabular}{c|c|c|c|c|c|c} 
& colour & number & $\mathrm{D}\left(^{\circ}\right)$ & $\mathrm{I}\left(^{\circ}\right)$ & $\mathrm{k}$ & $\alpha 95$ \\
\hline sites & red & 9 sites & 328 & -80.8 & 42.8 & 8 \\
\hline comp. & blue & 80 comp. & 337.4 & -79.5 & 10.5 & 5.2
\end{tabular}

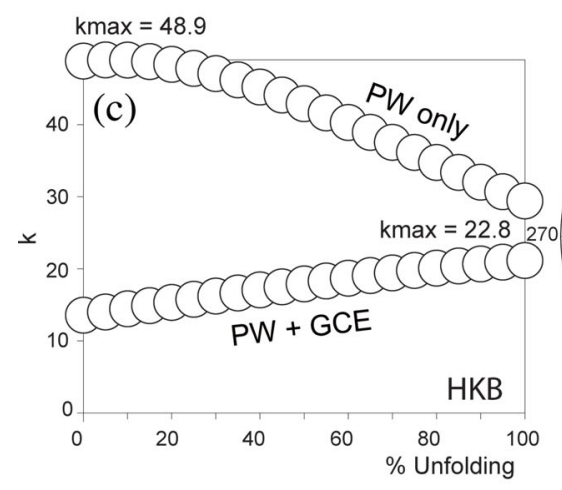

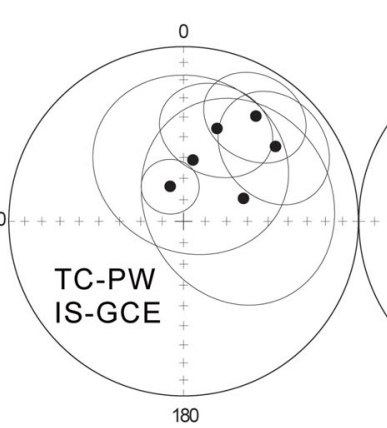

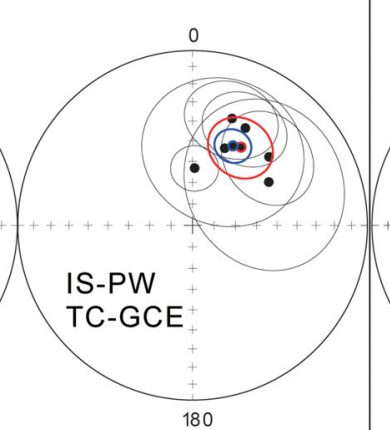

\begin{tabular}{c|c|c|c|c|c|r} 
& colour & number & $\mathrm{D}\left({ }^{\circ}\right)$ & $\mathrm{I}\left({ }^{\circ}\right)$ & \multicolumn{1}{c}{$\mathrm{k}$} & $\alpha 95$ \\
\hline sites & red & 6 sites & 31.7 & 47.2 & 22.8 & 14.2 \\
\hline comp. & blue & 37 comp. & 26.9 & 48.2 & 9.2 & 8.2
\end{tabular}

\section{Reversal test}

(b)

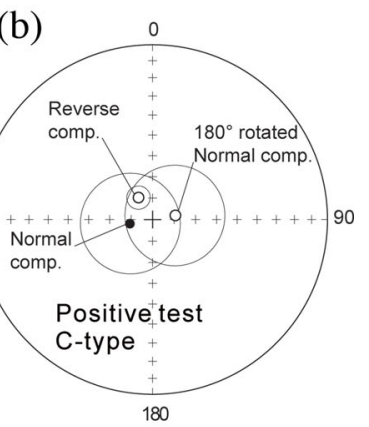

(d)

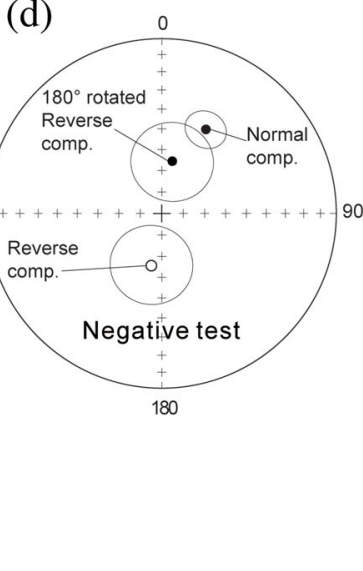

Figure 12. Fold (a) and (c) and reversal tests (b) and (d) for HKA and HKB components. The different tests have been performed under palaeomac software (Cogné 2003). (a) and (c) From left to right: binary diagrams showing the evolution of the dispersion parameter $k$ for progressive steps of unfolding of the bedding, and stereographic plots representing the in situ (i.e. unfolded) configuration (left) and the configuration minimizing $k$ (right). $\alpha_{95}=95$ per cent cones of confidence. (b) and (d) Stereographic plot showing the result of the reversal test with the average magnetization for normal and reverse polarity magnetizations. The red ellipses represent the mean of the considered site averages; and the blue ellipses the mean of all the considered component of magnetization from the whole studied area.

\subsection{Fold and reversal tests}

In order to evaluate the timing of remanence lock-in for the different magnetizations, we carried out the fold test and the reversal test according to McFadden's protocols (McFadden 1990; McFadden \& McElhinny 1990) on HKA and HKB components which are globally the two last components to be unblocked on the whole studied area. We performed the two statistical tests on the whole set of samples for the reversal test and 'regional' folds were restored to palaeohorizontal, that is, between the sites included in the Potchefstroom synclines (PW sites) and the two groups of sites that are part of monoclinal structures (GCE and DTH sites; Fig. 4). Note that sites containing less than four samples for one component, making unreliable the Fisher's mean values, were discarded for the calculation of the fold test.

Nine site means were considered for the HKA component (DTHB, GCE-B to GCE-E, PWA, PWB, PWC and PWE), being the last component to be demagnetized. We obtained positive results for both tests (Fig. 12a and Table 2). But due to the large uncertainties of the different site means and especially the low dip of the bedding, which never exceed $30^{\circ}$, it is difficult to obtain statistically significant results. However, the fold test improves the dispersion parameter $k$, by a factor of 2.5 which cannot be neglected. Such results suggest that the HKA component can be considered as a primary magnetization or at least recorded before any of the main folding deformation events (i.e. intrusion of the Bushveld Complex and formation of the Vredefort impact structure).

We performed the same tests on the sites and samples showing the HKB component in order to compare the timing acquisition of this component to the one of the main folding period, intrusion of the Bushveld Complex or formation of the Vredefort impact structure. The means of six sites were taken in account this time (sites PWB, PWC, PWE, GCE-B, GCE-C and GCE-E). The fold test is not significant as the dispersion is not really improved during backtilting of the bedding (Fig. 12b and Table 2). For the PW sites, a detailed analysis of the trajectory of unfolding highlights that the means of these sites move apart during backtilting implying a better grouping in situ. In addition, the GCE-site means converge to the in situ PW site means upon restoring beds to palaeohorizontal. As a consequence, the dispersion of the HKB components is optimized when considering the PW sites means in situ with the GCE sites means after bedding correction. It implies that the GCE sites were still untilted whereas the PW sites were 
already tilted when HKB were recorded. Finally, the reversal test is negative for the HKB components which supports an overprint interpretation for $\mathrm{HKB}$.

\section{DISCUSSION}

\subsection{Pole-pair characterization comparison and reconstruction}

We obtained five different components of magnetization namely, from the lowest to highest stability: HKE, HKD, HKC, HKB and HKA.

\subsubsection{Low-coercivity and/or temperature components (HKE)}

The 'softest' magnetic components, removed by low-field AF pretreatment up to $10 \mathrm{mT}$, have either scattered directions, or are aligned with the present geomagnetic field (PDF). The HKE component, which in individual samples only exists below $250{ }^{\circ} \mathrm{C}$, is interpreted as a viscous and/or low-temperature crystallization (i.e. linked to weathering) magnetization acquired during the Brunhes polarity epoch and the Matuyama polarity epoch for the sample showing a downward component (12 per cent of the samples). The means in situ matches the direction reported for the last $5 \mathrm{Myr}$ by Torsvik et al. (2012) for the studied area.

\subsubsection{Low/medium-coercivity and/or temperature components (HKD and $H K C)$}

The HKD and HKC components are competing overprints, and both are assumed to be thermoviscous, with HKC possibly being a chemical remanent magnetization, as it will be explained in this section. Only one sample (GCE-B5) records both components. The HKC component presents an unblocking temperature globally higher than HKD component, suggesting a relative anteriority of the event responsible of the HKC components. The HKD components have possibly totally remagnetized the same range of coercivity of the minerals bearing the HKC component. The relatively low and consistent range of temperature (i.e. $150-200^{\circ} \mathrm{C}$ up to $340^{\circ} \mathrm{C}$ ) for the HKD remanence in DTH sites alludes to pyrrhotite/greigite as main remanence carriers. For the PW and GCE sites, where the temperature range of HKD and HKD components are somewhat higher, thus highlighting that magnetite must also be a carrier.

The mean direction for the HKD magnetization has a declination of $309.9^{\circ}$ and an inclination of $-18.6^{\circ}\left(n=26, k=12.4, \alpha_{95}=8.6\right.$; Table 2). The tilt correction of bedding only results in a small change and does not provide a better cluster, and both components seem to have been acquired after the tilting of the units. The geographic (i.e. with no tilt correction) pole position is located at $39.8^{\circ} \mathrm{N}$ and $127.4^{\circ} \mathrm{E}(\mathrm{dp}=4.6$ and $\mathrm{dm}=8.9$; Table 3$)$. The best explanation of this overprint would be the emplacement of the widespread Karoo magmatism around $180 \mathrm{Ma}$ or the Cretaceous overprints (Hargraves et al. 1997) even if does not match perfectly with it (Fig. 13a). Occurrence of dykes and sills of the Karoo large igneous province (LIP) in the Kaapvaal craton and their overprint on the surrounding rocks are commonly observed (e.g. Salminen et al. 2009; Lubnina et al. 2010; Wabo et al. 2016a). On the other hand, because the PDF and the Karoo LIP poles are very difficult to discriminate (Table 3), some components from both thermal events could be mixed and this may explain the difference between our HKD pole and the Karoo LIP poles.
The HKC magnetization is characterized by declination of $207.1^{\circ}$ and an inclination of $18^{\circ}\left(n=40, k=11.2\right.$ and $\left.\alpha_{95}=7.1\right)$ giving a pole location of at $59.1^{\circ} \mathrm{N}$ and $88.5^{\circ} \mathrm{E}(\mathrm{dp}=3.8$ and $\mathrm{dm}=7.4)$. This location fits with none of the known directions from the Kaapvaal craton. Two likely hypothesis can explain this magnetization: (1) a thermoviscous remagnetization or a chemical remanent magnetization related to a metamorphic related thermal event and (2) a thermoviscous remagnetization linked to an igneous event. The relatively low unblocking temperature of $c a .200-400{ }^{\circ} \mathrm{C}$ for the HKD remanence (Table 2) indeed alludes to pyrrhotite/greigite as a possible remanence carrier. Then, the lower greenschist-facies metamorphism undergone by the whole the Transvaal Supergroup (Button 1973; Miyano \& Beukes 1984) might be responsible of either the neo-crystallization or the remagnetization of such minerals. This hypothesis was already argued for the ND remanence of de Kock et al. (2009b). Because of the abrupt decrease in coercivity as their Curie point is approached, pyrrhotite/greigite can be easily reset by low-grade thermal events (Hanus \& Krs 1968; Clark 1983); hence, in case of HKC, to an event happening before the Karoo magmatism and after the acquisition of HKB certainly related to $2.60-2.20 \mathrm{Ga}$ events as it will be discussed in the next section.

In case of igneous related thermal, the best-known candidate is the $\sim 1.1$ Ga Umkondo LIP (de Kock et al. 2014). The Umkondo LIP is represented by widespread mafic intrusions in the Kalahari craton (corresponding to the gathering of both Kaapvaal and Zimbabwe cratons). The HKC pole and the Umkondo pole as defined by Swanson-Hysell et al. (2015) are broadly similar, but do not overlap (Fig. 13a). Some arguments are in favour of considering an Umkondo LIP related origin for the HKC pole. First, except for poles from similar or slightly older age than $\sim 1.1 \mathrm{Ga}$ (e.g. the North Sishen Mine and the Premier Kimberlites poles; Table 3), no pole of the Kaapvaal craton was reported to lie at this position (or its corresponding reversal) so far. In addition, Salminen et al. (2009) characterized a remanence interpreted as related to emplacement of the Umkondo LIP in a gabbro intrusion in the northern part of the Vredefort structure, thus relatively close to the Hekpoort studied areas, especially the PW and DTH sites (Fig. 1). Finally, the Umkondo Grand Mean Pole of Swanson-Hysell et al. (2015) is calculated from 49 individual sites, with some of the individual site VGPs being very comparable to our HKC pole: especially the site WRD6 (VGP latitude $=-57.2$; longitude $=252.0$ or 72 once inverted) located in the eastern part of Pretoria, not far $\left(25^{\circ} 49^{\prime} 12.0^{\prime \prime} \mathrm{S} / 28^{\circ} 57^{\prime} 00.0^{\prime \prime} \mathrm{E}\right)$ from the GCE sites.

One can argue that no dyke or sill linked to the Karoo and Umkondo LIP or to any other event was observed in the sampled area. Yet, most of the study area display poor outcrops (except for the most silicified rocks). The less than perfect match between our poles with the ones of the Karoo and Umkondo LIP can also be linked to uncertainties in the bedding estimates: it is not compulsory that lava flows are cooled in a pure planar way whereas we always considered it as being the case in this work. However, we compared the bedding of lava units of most sites with those measured in the closest sedimentary layers (Fig. 4).

\subsubsection{High-coercivity and/or temperature components (HKB)}

Thirty-six samples represent the HKB component, showed by almost all sites from the PW and GCE sites but none from the DTH sites. The mean direction for the HKB magnetization has a declination of $26.9^{\circ}$ and an inclination of $48.2^{\circ}\left(k=10.2\right.$ and $\left.\alpha_{95}=8.2\right)$. The tilt-correction pole position is located at $28.4^{\circ} \mathrm{N}$ and $54^{\circ} \mathrm{E}$ 


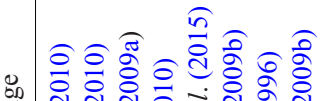

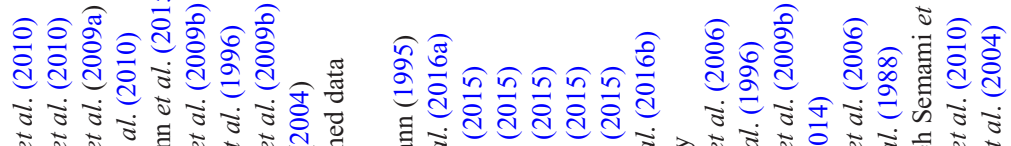

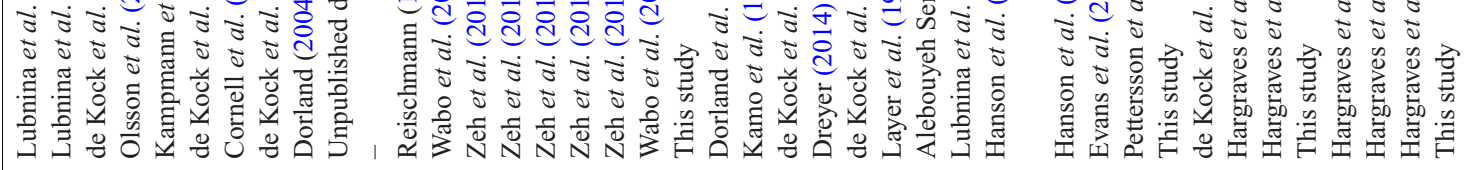

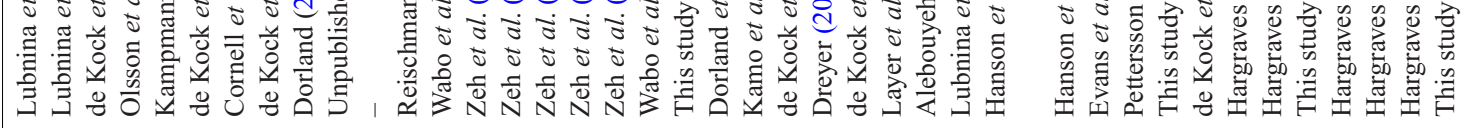

这

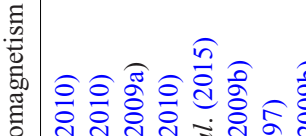

$\frac{\pi}{\pi}$

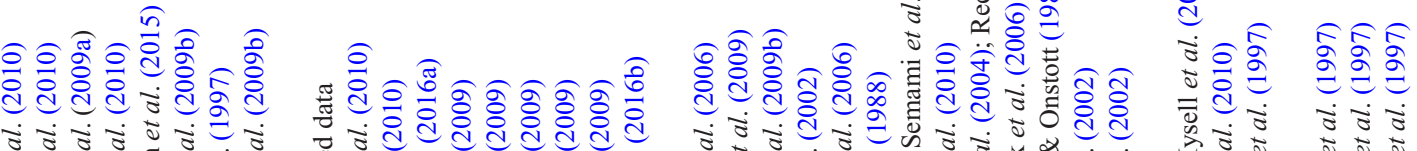

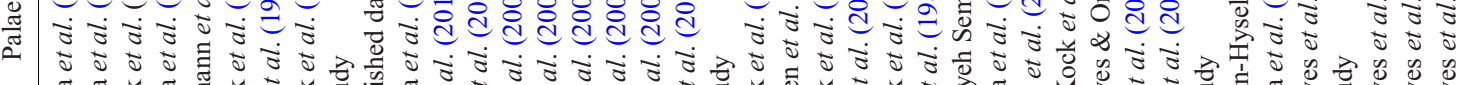

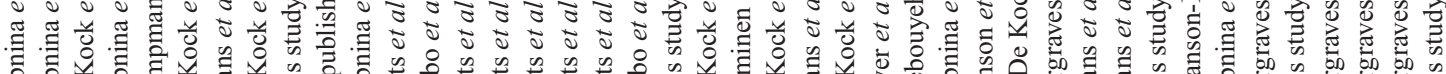

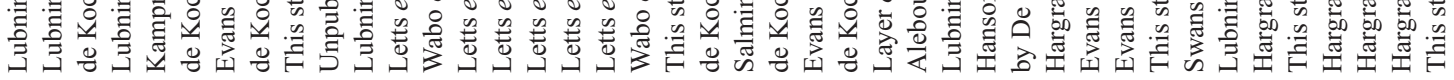

$\sum^{\pi} \sum^{\pi} \sum^{\pi} \sum^{\pi} \pi \approx \pi \sum^{\pi} \sum^{\pi} \sum^{\pi} \sum^{\pi} \sum^{\pi} \sum^{\pi}$

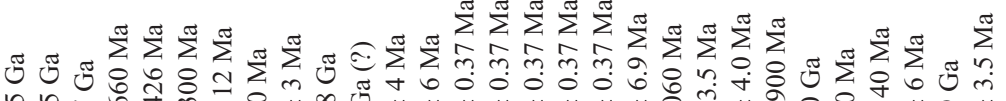

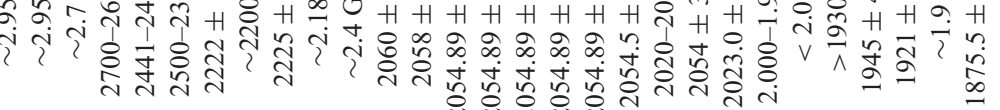

ง

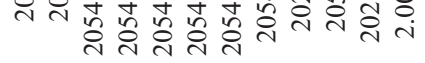

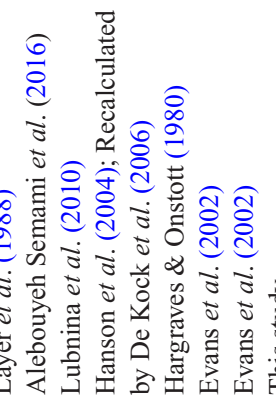

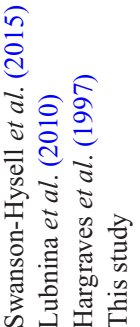

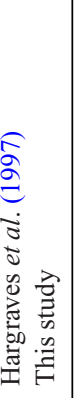

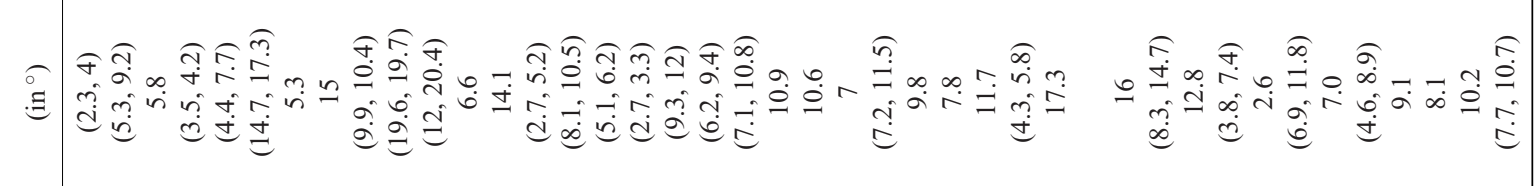

サ.

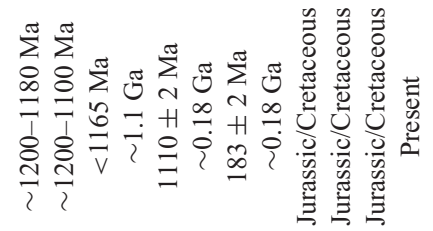

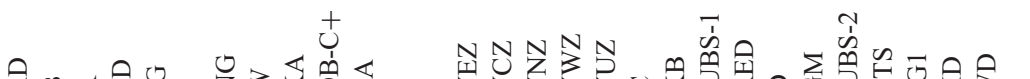

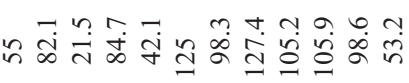

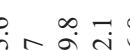

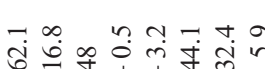

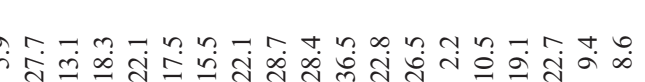

Ұ

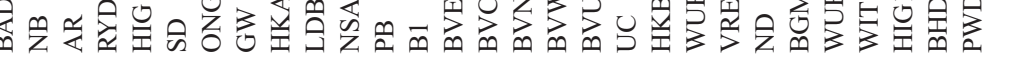

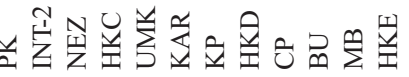

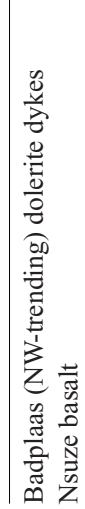

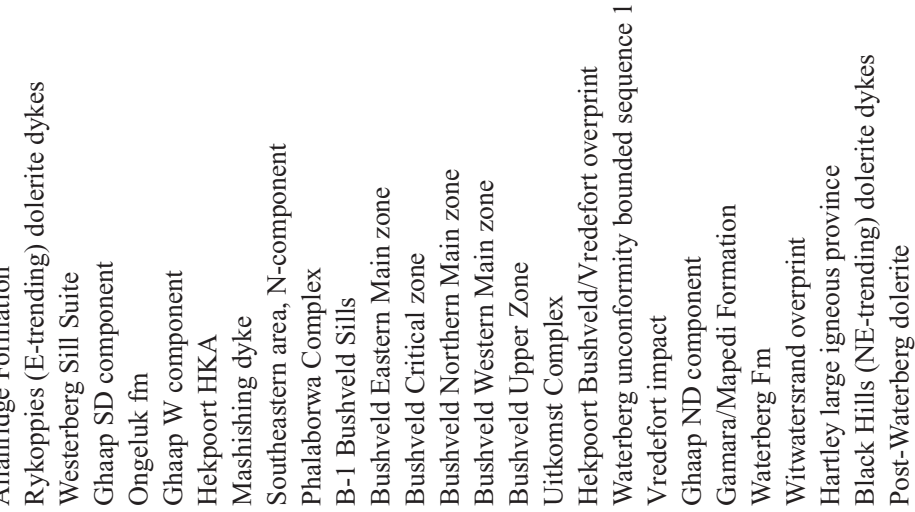

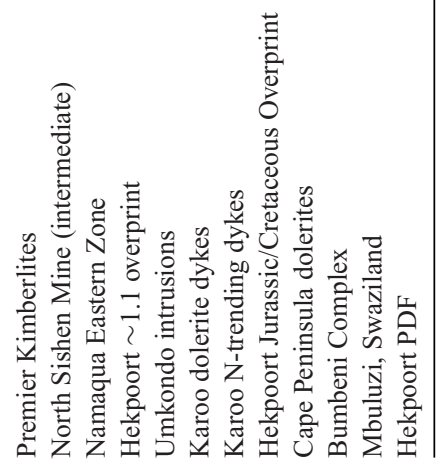




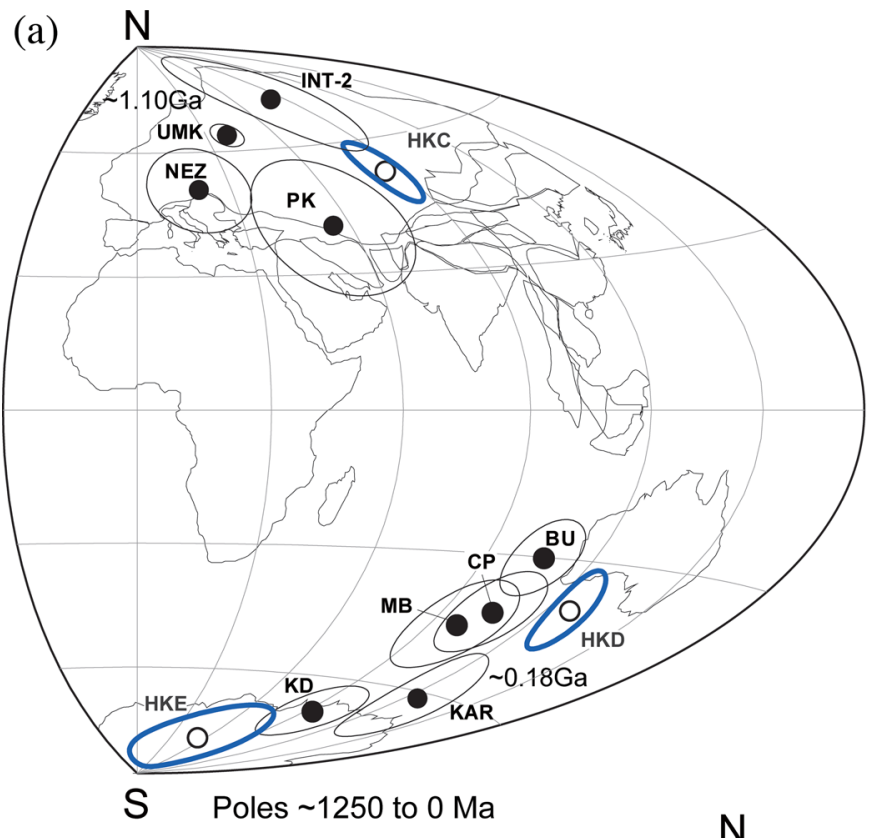

Poles 2060 to 2020Ma

\section{Bushveld Complex poles}

(b)

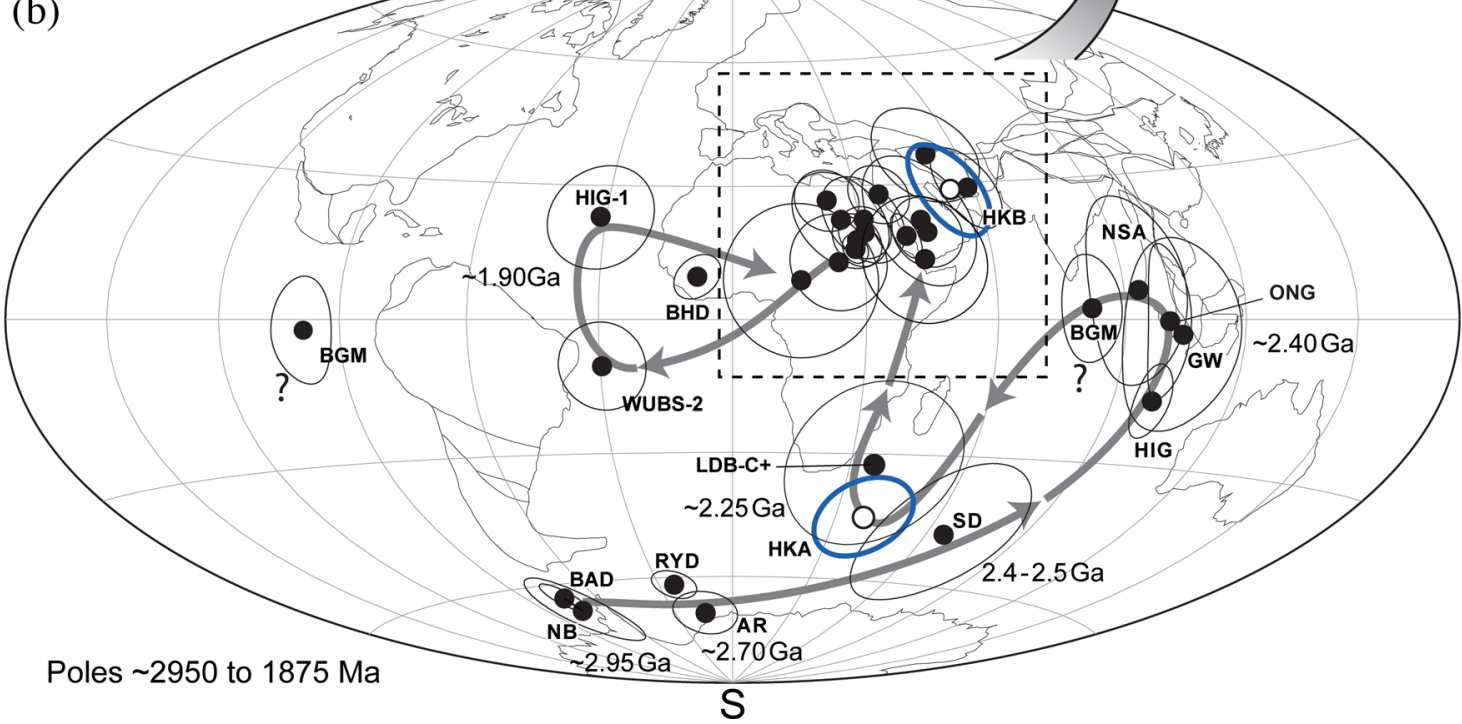

Figure 13. Comparison of the palaeomagnetic poles described by the five components identified in this study with known Palaeoproterozoic and Mesoproterozoic palaeopoles from the Kaapvaal craton (Table 3).

$(\mathrm{dp}=7.1$ and $\mathrm{dm}=10.8)$. This pole position can be easily associated with the period between $\sim 2.06$ and 2.02 Ga (Fig. 13b), marked by the two main events of the Kaapvaal craton, that is, Bushveld Complex (2.061-2.046 Ga) and the Vredefort impact structure $(2.023 \mathrm{Ga})$. These two events present poles location relatively similar (Fig. 13b and Table 3).

One can note the absence of reversal in the PW sites, while it is the case for the GCE sites (Fig. 11). Normal and inverse primary magnetizations were also characterized in the Bushveld Complex (Letts et al. 2009), while the impact related magnetization of the Vredefort structure is supposed to be instantaneous, especially at the distance from the main impact zone (Fig. 1). Hence, the downward and upward components in the GCE sites can be explained by polyphased thermoviscous remagnetization due to the Bushveld Complex during the periods of normal and inverse magnetic fields.
On the other hand, similar thinking cannot be done concerning the PW sites. The absence of reversal in such suites being linked to the implementation of either the Bushveld Complex during an epoch showing no reversal or to the Vredefort impact structure.

Regarding the DTH sites, it is hardly possible to declare with certitude if either they never contained the HKB components or it was actually recorded until a later event completely overprinted it. If the HKB components of the PW sites are related to the Vredefort impact structure, similar results can be expected concerning the DTH sites, situated at comparable distance to the main Vredefort impact area (Fig. 1). According the bimodal behaviour of the DTH sites (i.e. either showing HKC or HKD components), this hypothesis required that the $\mathrm{HKB}$ components was remagnetized by the $\mathrm{HKC}$ or HKD components following the samples, which remain unlikely, but not impossible. 


\subsubsection{High-coercivity and temperature primary components (HKA)}

The primary component HKA, present in 80 samples, shows, respectively, 69 upward and 11 downward subvertical components. This magnetization is widely represented by all the sites providing exploitable results, in the exception of DTH-A and DTH-C. The tilt correction of bedding results in moderate inclination change but provides a better cluster (Table 3). The mean direction of the HKA magnetization present a declination of $337.4^{\circ}$ and an inclination of $-79.5^{\circ}\left(k=10.5\right.$ and $\left.\alpha_{95}=5.2\right)$. The corresponding tiltcorrected pole position is located at $-44.1^{\circ} \mathrm{N}$ and $40^{\circ} \mathrm{E}(\mathrm{dp}=9.9$ and $\mathrm{dm}=10.4$ ).

The presence of both reversal and the positive fold test allow us to pretend that obtained pole is a ChRM of the $\sim 2225 \mathrm{Ma}$ Hekpoort Formation (Van der Voo 1990), implying that HKA is a thermoremanent magnetization. In addition, there is no resemblance between position of the HKA with palaeopoles of younger ages, except concerning some Phanerozoic period (Figs 13a and b). The only poles close to the HKA ones are the pole of the $2.782 \pm 5 \mathrm{Ma}$ Derdepoort basalt and the SD pole characterized by de Kock et al. (2009b) in several formations of the Ghaap Group (Fig. 13b and Table 3), that is, the first of the two groups composing the Transvaal Supergroup in the Griqualand basin (Fig. 2).

Finally, one can note the non-concordance between our poles and the palaeopoles of the Ongeluk Formation characterized by Evans et al. (1997).

\subsection{Implications concerning the evolution of the Transvaal Basin}

A comparison between the Transvaal and the Griqualand West basins is represented in Fig. 2. The majority of the age determinations on them matched in the lower sections of the stratigraphies, but less convincing for the upper parts of the stratigraphies. This comparison can be qualified as 'traditional' chronostratigraphy because it was used by many previous works (e.g. Cornell et al. 1996; Evans et al. 2002; Eriksson et al. 2006; Guo et al. 2009; Lenhardt et al. 2012). According to Moore et al. (2001) correlation of the Pretoria and Postmasburg Groups has essentially hinged around the similarities between thick basaltic-andesite volcanic units in the two sequences (eastern Hekpoort Formation and western Ongeluk Formation) in both, composition and model age (Sharpe et al. 1983; Cornell et al. 1996). The non-equivalence of the palaeopoles of the Hekpoort Formation and Ongeluk Formation, respectively, HKA and ONG (Fig. 13b and Table 3), can be explained by two different scenarios: either (1) both formations are from different ages, hence, the correspondence between the Transvaal and the Griqualand West basins of Fig. 2 is wrong (Fig. 14a) or (2) the two formations have the same age and one of the those two palaeopoles is not primary, presumably HKA (Fig. 14b). Even if the first hypothesis seems to be the more likely one according the age dating presented in Sections 2.2 and 2.3, in this section we will successively discus those two hypothesis and all the data from the literature supporting either one or the other.

\subsubsection{A 200 Ma gap between the Hekpoort and Ongeluk Formations}

Even if the Hekpoort Formation and Ongeluk Formation have often been compared without reaching any unilateral consensus (see the Introduction), the newly published baddeleyite age of $2426 \pm 3 \mathrm{Ma}$ for the Ongeluk Formation (Gumsley et al. 2016, 2017) is in favour for a 200 Ma gap between the two formations. Moore et al. (2012) also estimate the Postmasburg Group to be older than the Pretoria Group based on dating of detrital zircon. These authors did not observe any zircons younger than $\sim 2.4 \mathrm{Ga}$ in both the Maganyene and Hotazel Formations (Postmasburg Group), while some zircons showing minimum ages down to $\sim 2.2 \mathrm{Ga}$ were obtained in the other Group (from the Timeball Hill to the Magaliesberg formations; Schröder et al. 2016).

In Fig. 13(b), we present an Apparent Pole Wander Path going through the Ongeluk palaeopole (ONG), which can then be interpreted as representing the relative polar movement of the Kaapvaal craton around $2.4 \mathrm{Ga}$, then the palaeopole of the Hekpoort Formation HKA, which is consequently supposed to be representative of the $\sim 2.25 \mathrm{Ga}$ palaeopole of the craton. In addition to the VGP of the Ongeluk Formation, this $\sim 2.4$ Ga pole group includes the high stability VGP of the Westerberg Sills Suite (HIG; Kampmann et al. 2015) and the SD (the Ghaap group; de Kock et al. 2009b) and NSA (from a Palaeoproterozoic dyke in the Kaapvaal craton; Lubnina et al. 2010) palaeopoles. Despite this, only the HIG palaeopole is associated with an age, that is, $2441 \pm 6$ and $2426 \pm 1 \mathrm{Ma}$ (baddeleyite $\mathrm{U}-\mathrm{Pb}$ isochron; Kampmann et al. 2015); the two other poles are only assumed to belong to the same group. Note that the pole determined from the weathering profile that developed below the unconformity at the base of Gamagara-Mapedi Formation (BGM; Evans et al. 2002) is presenting similar coordinates. Yet, even if those two formations were supposed to be part of the Transvaal Supergroup (e.g. Evans et al. 2002; Eriksson et al. 2006; Guo et al. 2009; Lenhardt et al. 2012), detrital zircon of U-Pb ages between $\sim 2.01$ and 1.98 Ga (da Silva 2011; Dreyer 2014) coupled with the age of the Hartley lavas at $1928 \pm 4$ Ma (Alebouyeh Semami et al. 2016) strongly suggests that this sequence actually only belongs to the Olifantshoek Supergroup. This explains why, we excluded the Gamara, Mapedi and Lucknow formations from the Transvaal Supergroup in Fig. 14.

The current geochronological database implies that the two basins at least partly evolved during different periods and not synchronously as suggested by different works (e.g. Eriksson et al. 2006). This also signifies a Postmasburg Group older than the whole Pretoria Group, and the absence of any equivalence or preserved equivalent units in the other basin (Fig. 14a). This model also considerably reduce the time gap between the Koegas Subgroup and the Makganyene Formation than represented in Fig. 2, and thus between Ghaap and Postmasburg Groups.

\subsubsection{Possibilities of HKA to be an overprint}

The newly obtained $\sim 2426 \mathrm{Ma}$ age of Ongeluk Formation is however not totally answering all the controversy in the debate comparing the Hekpoort Formation and Ongeluk Formation. Beukes et al. (2013) characterized a notable detrital zircons population of $\mathrm{U}-\mathrm{Pb}$ age around $2.2 \mathrm{Ga}$ (the youngest being $2226 \pm 42 \mathrm{Ma}$ ) were characterized in several samples from the Maganyene formations (and Hotazel) underlying the ONG, and are thus in disagreement with the results of Moore et al. (2012) and, in an obvious way, also the new Ongeluk age of Gumsley et al. (2016, 2017). Such results may affect the whole model of an Ongeluk Formation around $\sim 2.4 \mathrm{Ga}$; model which hitherto seemed consistent regarding the other results presented in this section. Moreover, geochemical data of both Ongeluk and Hekpoort Formations strongly suggest a comagmatic origin (Humbert et al., 
(a)

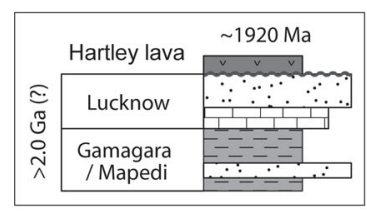

No equivalents or preserved equivalents in the Griqualand West basin

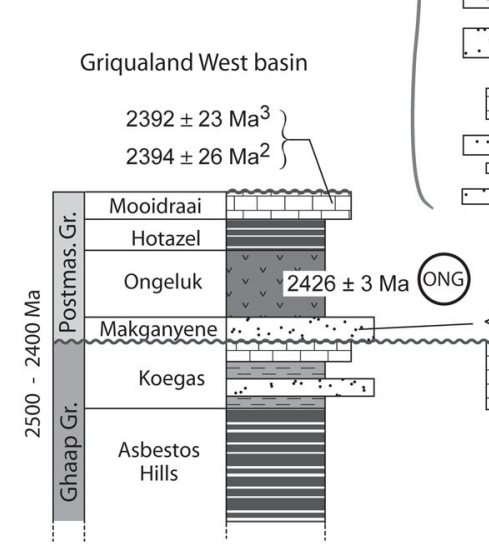

Transvaal basin

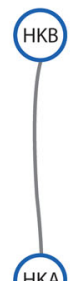

Bushveld Intrusion $\sim 2055 \mathrm{M}$

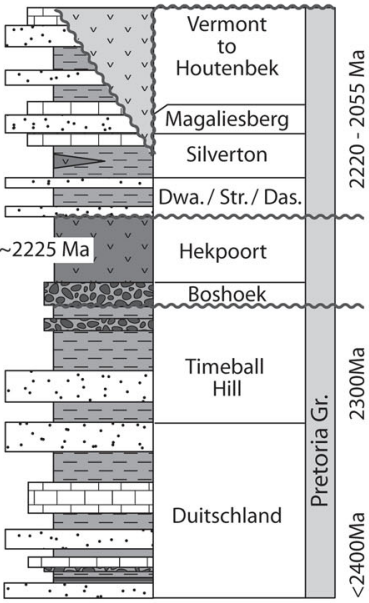

Figure 14. (a) Modification of the chronostratigraphy of the Transvaal Supergroup presented in Fig. 2 according the hypothesis presented in Fig. 13(b) (i.e. HKA = primary pole). (b) Alternative hypothesis of the APWP presented in Fig. 13(b). The HKA palaeopole corresponds here to a remagnetization from a primary palaeopole HK0, occurring after the emplacement of the Hekpoort Formation, coeval with the Ongeluk Formation, and before the creation of the HKB palaeopole by the Bushveld Complex and/or the Vredefort impact structure. Age dating are from: (1) Moore et al. (2012), (2) Bau et al. (1999), (3) Fairey et al. (2013) and (4) Beukes et al. (2013).

in preparation). Both formations present identical geochemical patterns (i.e. rare earth element and multielement patterns) and the exact same evolution by crystal fractionation. The similarity between the geochemical data of the Ongeluk and Hekpoort Formations is a unique case in the Kaapvaal craton (Humbert et al., in preparation). Unlike what was concluded by Myers et al. (1987), all mafic igneous formations from $\sim 3.0 \mathrm{Ga}$ to the $\sim 0.18 \mathrm{Ga}$ Karoo LIP present different geochemical pattern, specific to each magmatic event or to each step of magma evolution in one magmatic event.

In the light of such data, it is not unthinkable that the inadequacy between our primary pole HKA and the ONG palaeopole can then be solved in an another way: the two formations have the same age $(\sim 2.25 \mathrm{Ga})$ and one of those two palaeopoles might be related to an overprint and then not acquired during the extrusion of the lavas. We first took in consideration that the ONG palaeopole (Evans et al. 1997) is possibly linked to an overprint. Evans et al. (1997) indeed only obtained two components, in the Ongeluk volcanics, that is, the present geomagnetic field and the primary ones which can be surprising following the age of such rocks. Having said that, it seems unlikely that this ONG palaeopole is an overprint for several reasons: (1) Evans et al. provided enough field test (including a positive conglomerate test) to prove with a certain confidence that their palaeopole is primary, (2) the Griqualand basin was less submitted to 'intense' geological events (i.e. limited impact from the Bushveld Complex and Vredefort impact structure) in comparison to the Transvaal basin, which may explain the lack of overprint relatively to our samples.

The ONG palaeopole also share similar coordinates as the $\sim 2.43 \mathrm{Ga}$ Westerberg Sill Suite palaeopole (HIG), which is (b)
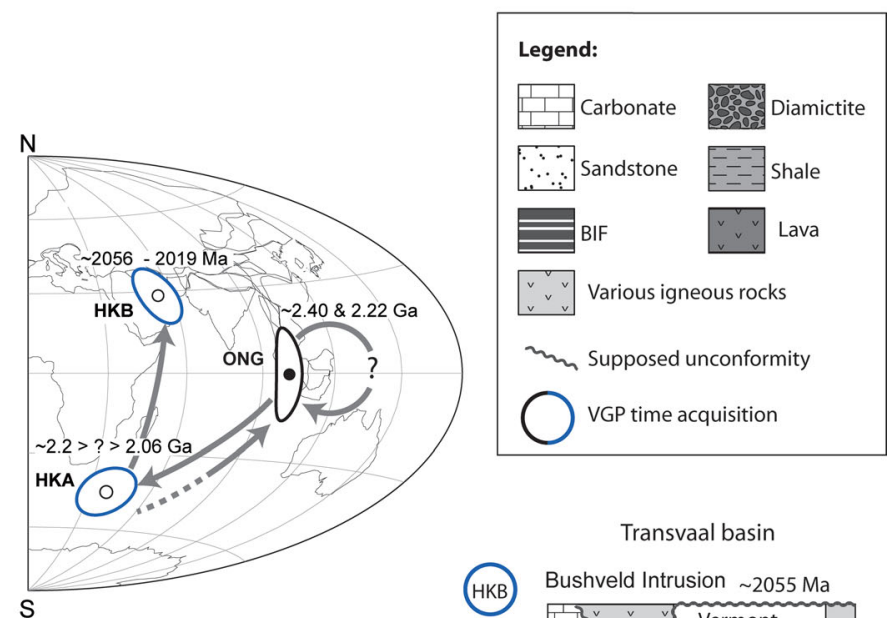

Transvaal basin

$\mathrm{S}$

Bushveld Intrusion $\sim 2055 \mathrm{Ma}$

Griqualand-West basin

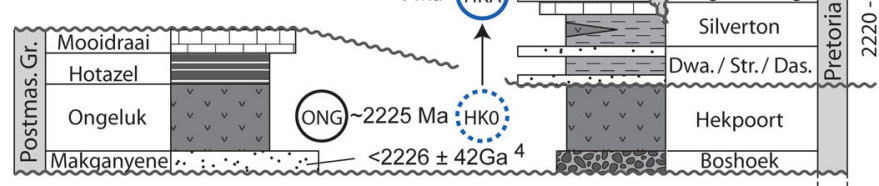

either contradicting the $\sim 2.25 \mathrm{Ga}$ for the Ongeluk Formation or highlighting that the $\sim 2.4$ and $\sim 2.25$ Ga palaeopole s presents similar components (Fig. 12b). This second hypothesis also implies that the highest coercivity component HKA to be a thermoviscous overprint resulting from a geological event, certainly igneous related and post extrusion of the Hekpoort lavas, which occurred in the whole studied area. This hypothetical event must have been developed before the emplacement Bushveld Complex, whose influence is represented by the overprint components HKB in our samples. Likewise, this is supported by the better correlation of the HKA components after the untilting process, giving an origin before the setting Bushveld Complex and the Vredefort structure. Besides, the period between the Hekpoort Formation and the Bushveld Complex is rich in relatively little studied magmatic events, mainly in the eastern part of the Transvaal basin (i.e. the Machadodorp member; the $2.2 \mathrm{Ga}-2.1 \mathrm{Ga}$ dyke swarms; the Dullstroom Formation). Furthermore, it must have happened at a significant time before the Bushveld Complex, according to the difference between our HKA pole and the Bushveld palaeopoles (Fig. 13b). Some data are indeed arguing in favour in this overprint. A virtual geomagnetic pole (LDB-C+; based on 10 samples; Wabo 2014), characterized in one dyke belonging to the Mashishing (Lydenburg) area (Fig. 1) and showing an $\mathrm{Ar}-\mathrm{Ar}$ age of $\sim 2.18 \mathrm{Ga}$ (Wabo, 2016, personal communication), plots close to our HKA pole (Fig. 13b). This dyke is obviously not responsible for the whole remagnetization of the Hekpoort Formation in the studied area presented here, but can indicate that the $\sim 2.18$ Ga correspond to the time when the Hekpoort Formation rocks got the overprint that we called HKA in this paper (Fig. 14b). The presence of reversals might be considered against 
such idea; but only 15 per cent of the samples nonetheless show downward vectors (in opposition to the upward ones representing the main cluster of components; Fig. 11).

In the view of all the data, one can see that more data are now in favour for a significant timing difference between the Ongeluk and Hekpoort Formations. Yet, it is not the purpose of this present work to conclude here with certainty the long debate of ruling with certainty about the correspondence or not between the Postmasburg and Pretoria Groups, because, even if it seems less likely, the highest coercivity palaeopole characterized in this contribution can be not primary.

More and better age dating will help to resolve this debate, together with new palaeomagnetic studies on the igneous units occurring during the period between the Hekpoort Formation and the Bushveld Complex, that is, the possible 2.2 dyke swarm and the Machadodorp member in the Silverton Formation.

\section{CONCLUSIONS}

Rocks of the Palaeoproterozoic Hekpoort Formation in the Transvaal Basin revealed a complicated magnetic history that spans about 2 billion years of the geological evolution of the Kaapvaal craton. During this study, a total of five remanent directions we named HKE to HKA were identified. Four of which were readily shown to be either viscous magnetizations, in correlation to the present geomagnetic field (HKE), or thermoviscous magnetizations related the Karoo magmatism around $0.18 \mathrm{Ga}(\mathrm{HKD})$, possibly the Umkondo magmatism around $1.11 \mathrm{Ga}$ (HKC) and the Bushveld event and/ or the Vredefort impact structure (HKB) at a period around 2.06-2.02 Ga. The fifth component (HKA) was isolated in most sites as the most stable remanence and is supposed to be the primary magnetic direction of the Hekpoort lavas, based on a positive fold test. The corresponding palaeopole, however, $\left(44.1^{\circ} \mathrm{S}\right.$ and $40^{\circ} \mathrm{E} ; \mathrm{dp}=9.9$ and $\mathrm{dm}=10.4$ ) is different from the palaeopole reported by previous authors from the Ongeluk Formation in the Griqualand basin which was supposed to be coeval the Hekpoort Formation. This suggests either that the two formations are probably not contemporaneous or that our HKA pole may not be primary.

\section{ACKNOWLEDGEMENTS}

We would like to thank the reviewers, Richard Hanson and Sergei Pisarevsky, as well as two editors, Eduard Petrovsky and Sylvia Hales, whose comments and suggestions have improved the manuscript considerably. Funding was provided by grants from South African Department of Science and Technology and the National Research Foundation (DST-NRF)-funded Centre of Excellence for Integrated Mineral and Energy Resource Analysis (CIMERA).

\section{REFERENCES}

Alebouyeh Semami, F., De Kock, M.O., Söderlund, U., Gumsley, A., Da Silva, R., Beukes, N. \& Armstrong, R., 2016. New U-Pb geochronology and paleomagnetic constraints on the late Paleoproterozoic Hartley magmatic event: evidence for a Large Igneous Province in the Kaapvaal craton during Kalahari assembly, South Africa, GFF, 138, 164-182.

Altermann, W. \& Hälbich, I.W., 1991. Structural history of the south-western corner of the Kaapvaal craton and the adjacent Namaqua realm: new observations and reappraisal, Precambrian Res., 52, 133-166.

Bau, M., Romer, R.L., Lüders, V. \& Beukes, N.J., 1999. Pb, O, and C isotopes in silicified Mooidraai dolomite (Transvaal Supergroup, South
Africa): implications for the composition of Paleoproterozoic seawater and 'dating' the increase of oxygen in the Precambrian atmosphere, Earth planet. Sci. Lett., 174, 43-57.

Beukes, N.J., Dorland, H.C., Gutzmer, J., Nedachi, M. \& Ohmoto, H., 2002. Tropical laterites, life on land, and the history of atmospheric oxygen in the Paleoproterozoic, Geology, 30, 491-494.

Beukes, N.J., Frei, D. \& Vorster, C., 2013. Detrital zircon age constraint of the Makganyene Snowball Earth Event (South Africa) at 2.25-2.22 Ga: the youngest of four Huronian glaciations?, [abst.] Geol. Soc. Am. Abstr. Prog., 45(7), 340.

Button, A., 1973. A regional study of the stratigraphy and development of the Transvaal Basin in the eastern and northeastern Transvaal, PhD thesis, University of Witwatersrand, Johannesburg, $352 \mathrm{pp}$.

Cheney, E.S., 1996. Sequence stratigraphy and plate tectonic significance of the Transvaal succession of Southern Africa and its equivalent in Western Australia, Precambrian Res., 79, 3-24.

Clark, D.A., 1983. Paleomagnetism of pyrrhotite-bearing rocks. 1438R, CSIRO Restricted Investigation Report. North Ryde, NSW, Australia.

Coertze, F.J., Burger, A.J., Walraven, F., Marlow, A.G. \& MacCaskie, D.R., 1978. Field relations and age determinations in the Bushveld Complex. Trans. geol. Soc. S. Afr., 81, 1-11.

Cogné, J.P., 2003. PaleoMac: a Macintosh TM application for paleomagnetic data and making plate reconstructions, Geochem. Geophys. Geosyst., 4, 1007, doi:10.1029/2001GC000227.

Cornell, D.H., Schütte, S.S. \& Eglington, B.L., 1996. The Ongeluk basaltic andesite formation in Griqualand West, South Africa: submarine alteration in a 2222 Ma Proterozoic sea, Precambrian Res., 79, 101-123.

Da Silva, R., 2011. Distribution and geochronology of unconformity-bound sequences in paleoproterozoic Elim-Olifantshoek red beds: implications for timing of formation of Sishen-type iron ore and heavy carbonate carbon isotope excursion, MSc thesis, University of Johannesburg, Johannesburg, South Africa, 110 pp., unpublished

Dekkers, M.J., 1989. Magnetic-properties of natural goethite. 1. Grain-size dependence of some low- field and high-field related rock-magnetic parameters measured at room-temperature, Geophys. J., 97, 323-340.

de Kock, M.O., Evans, D.A.D., Dorland, H.C., Beukes, N.J. \& Gutzmer, J., 2006. Paleomagnetism of the lower two unconformity-bounded sequences of the Waterberg Group, South Africa: towards a better-defined apparent polar wander path for the Paleoproterozoic Kaapvaal craton, S. Afr. J. Geol., 109, 157-182.

de Kock, M.O., Evans, D.A.D., Kirschvink, J.L., Beukes, N.J., Rose, E. \& Hilburn, I., 2009a. Paleomagnetism of a Neoarchean-Paleoproterozoic carbonate ramp and carbonate platform succession (Transvaal Supergroup) from surface outcrop and drill core, Griqualand West region, South Africa, Precambrian Res., 169, 80-99.

de Kock, M.O., Evans, D.A.D. \& Beukes, N.J., 2009b. Validating the existence of Vaalbara in the late Neoarchean, Precambrian Res., 174, 145154 .

de Kock, M.O. et al., 2014. Dykes of the 1.11 Ga Umkondo LIP, Southern Africa: clues to a complex plumbing system, Precambrian Res., 249, 129-143.

Dorland, H.C., 2004. Provenance ages and timing of sedimentation of selected Neoarchean and Paleoproterozoic successions on the Kaapvaal craton, PhD thesis, University of Johannesburg, Johannesburg, South Africa, 326 pp., unpublished.

Dorland, H.C., Beukes, N.J., Gutzmer, J., Evans, D.A.D. \& Armstrong, R.A., 2006. Precise SHRIMP U-Pb zircon age constraints on the lower Waterberg and Soutpansberg Groups, South Africa, S. Afr. J. Geol., 109, 139-156.

Dreyer, D., 2014. Geochronology and correlation of Paleoproterozoic red beds of the Elim Group in the Griqualand West Northern Cape Province, MSc thesis, University of Johannesburg, Johannesburg, South Africa, unpublished.

du Toit, A.L., 1926. The Geology of South Africa, Oliver \& Boyd, 444 pp.

Dunlop, D.J. \& Özdemir, Ö., 1997. Rock Magnetism: Fundamentals and Frontiers, Cambridge Univ. Press, 573 pp.

Eriksson, P.G., Altermann, W. \& Hartzer, F.J., 2006. The Transvaal Supergroup and its precursors, in The Geology of South Africa, pp. 237-260, 
eds Johnson, M.R., Anhaeusser, C.R. \& Thomas, R.J.,. Geol. Soc. S. Afr., Council for Geoscience, Pretoria, Johannesburg.

Eriksson, P. \& Cheney, E.S., 1992. Evidence for the transition to an oxygenrich atmosphere during the evolution of red beds in the Lower Proterozoic sequences of southern Africa, Precambrian Res., 54, 257-269.

Eriksson, P.G. \& Reczko, B.F.F., 1995. The sedimentary and tectonic setting of the Transvaal Supergroup floor rocks to the Bushveld Complex: tectonic setting derived from basin-fill geometry, inferred volcanic processes and sedimentation systems, J. Afr. Earth Sci., 21, 487-504.

Eriksson, P.G., Schweitzer, J.K., Bosch, P.J.A., Schreiber, U.M., van Deventer, J.L. \& Hatton, C.J., 1993. The Transvaal sequence: an overview, J. Afr. Earth Sci., 16, 25-51.

Evans, D.A.D., Beukes, N.J. \& Kirschvink, J.L., 1997. Low-latitude glaciation in the Palaeoproterozoic era, Nature, 386, 262-266.

Evans, D.A.D., Beukes, N.J. \& Kirschvink, J.L., 2002. Palaeomagnetism of a lateritic paleoweathering horizon and overlying Paleoproterozoic red beds from South Africa: implications for the Kaapvaal apparent polar wander path and a confirmation of atmospheric oxygen enrichment, J. geophys. Res., 107, 1-22.

Fairey, B., Tsikos, H., Corfu, F. \& Polteau, S., 2013. U-Pb systematics in carbonates of the Postmasburg Group, Transvaal Supergroup, South Africa: primary versus metasomatic controls, Precambrian Res., 231, 194-205.

Frick, C., 1973. The Sill phase and chill zone of the Bushveld Igneous Complex, Trans. geol. Soc. S. Afr., 76, 7-14.

Gardner, J.E., Befus, K.S., Miller, N.R. \& Monecke, T., 2014. Cooling rates of mid-ocean ridge lava deduced from clinopyroxene spherulites, J. Volc. Geotherm. Res., 282, 1-8.

Guo, Q. et al., 2009. Reconstructing Earth's surface oxidation across the Archean-Proterozoic transition, Geology, 37, 399-402.

Gumsley, A.P., Chamberlain, K., Bleeker, W., Söderlund, U., de Kock, M.O., Kampmann, T.C., Larsson, E. \& Bekker, A., 2016. The timing of the palaeoproterozoic great oxidation event using dykes, sills and bolcanics of the ongeluk large igneous province, kaapvaal craton, Acta Geol. Sin., 90, 67-68.

Gumsley, A.P., Chamberlain, K., Bleeker, W., Söderlund, U., de Kock, M.O., Larsson, E. \& Bekker, A., 2017. The timing and tempo of the Great Oxidation Event, Proc. Natl. Acad. Sci. USA, 114, 1811-1816.

Gutzmer, J. \& Beukes, N.J., 1998. High-grade manganese ores in the Kalahari man-ganese field: characterization and dating of the ore forming events. University of Johannesburg, South Africa, 221 p., unpublished.

Gutzmer, J., Banks, D.A., Lüders, V., Hoefs, J., Beukes, N.J. \& von Bezing, K.L., 2003. Ancient sub-seafloor alteration of basaltic andesites of the Ongeluk Formation, South Africa: implications for the chemistry of Paleoproterozoic seawater, Chem. Geol., 201, 37-53.

Hannah, J.L., Bekker, A., Stein, H.J., Markey, R.J. \& Holland, H.D., 2004. Primitive Os and $2316 \mathrm{Ma}$ age for marine shale: implications for Paleoproterozoic glacial events and the rise of atmospheric oxygen, Earth planet. Sci. Lett., 225, 43-52.

Hanski, E.J., 1993. Globular ferropicritic rocks at Pechenga, Kola Peninsula (Russia) liquid immiscibility versus alteration, Lithos, 29, 197-216.

Hanson, R.E. et al., 2004. Paleoproterozoic intraplate magmatism and basin development on the Kaapvaal craton: age, paleomagnetism and geochemistry of $\sim 1.93$ to $\sim 1.87$ Ga post-Waterberg dolerites, S. Afr. J. Geol., 107, 233-254.

Hanson, R.E. et al., 2006. Mesoproterozoic intraplate magmatism in the Kalahari: a review, J. Afr. Earth Sci., 46, 141-167.

Hanus, V. \& Krs, M., 1968. Applicability of palaeomagnetism of pyrrhotite to oregenetic studies, Mineral. Depos., 3, 242-248.

Hargraves, R.B. \& Onstott, T.C., 1980. Paleomagnetic results from some southern African kimberlites, and their tectonic significance, J. geophys. Res., 85, 3587-3596.

Hargraves, R.B., Rehacek, J. \& Hooper, P.R., 1997. Palaeomagnetism of the Karoo igneous rocks in southern Africa, S. Afr. J. Geol., 100, $195-212$.

Hartzer, F.J., 1995. Transvaal Supergroup inliers: geology, tectonic development and relationship with the Bushveld Complex, South Africa, J. Afr. Earth Sci., 21, 521-547.
Henkel, H. \& Reimold, W.U., 1998. Integrated geophysical modelling of a giant, complex impact structure: anatomy of the Vredefort Structure, South Africa, Tectonophysics, 287, 1-20.

Hoffman, P.F., 2013. The Great Oxidation and a Siderian snowball Earth: MIF-S based correlation of Paleoproterozoic glacial epochs, Chem. Geol., 362, 143-156.

Johnson, M.R., Anhaeusser, C.R. \& Thomas, R.J., 2006. The Geology of South Africa, Council for Geoscience Book, Pretoria, 691 p.

Jones, C.H., 2002. User-driven integrated software lives: 'Paleomag' Paleomagneticanalysis on the Macintosh, Comp. Geosci., 28, 1145-1151.

Kamo, S.L., Reimold, W.U., Krogh, T.E. \& Colliston, W.P., 1996. A 2.023 $\mathrm{Ga}$ age for the Vredefort impact event and a first report of shock metamorphosed zircons in pseudotachylitic breccias and Granophyre, Earth planet. Sci. Lett., 144, 369-387.

Kampmann, T., Gumsley, A.P., de Kock, M.O. \& Söderlund, U., 2015. U-Pb geochronology and paleomagnetism of the Westerberg Sill Suite, Kaapvaal craton-support for a coherent Kaapvaal-Pilbara Block (Vaalbara) into the Paleoproterozoic?, Precambrian Res., 269, 58-72.

Kirschvink, J.L., 1980. The least-squares line and plane and the analysis of palaeomagnetic data, Geophys. J. R. Astron. Soc., 62, 699-718.

Kirschvink, J.L., Kopp, R.E., Raub, T.D., Baumgartner, C.T. \& Holt, J.W., 2008. Rapid, precise, and high-sensitivity acquisition of paleomagnetic and rock-magnetic data: development of a low-noise automatic sample changing system for superconducting rock magnetometers, Geochem. Geophys. Geosyst., 9, 1-18.

Layer, P.W., Kröner, A., McWilliams, M. \& Clauer, N., 1988. Regional magnetic over-printing of Witwatersrand Supergroup Sediments, South Africa, J. geophys. Res., 93, 2191-2200.

Lenhardt, N., Eriksson, P.G., Catuneanu, O. \& Bumby, A.J., 2012. Nature of and controls on volcanism in the ca. 2.32-2.06 Ga Pretoria Group, Transvaal Supergroup, Kaapvaal craton, South Africa, Precambrian Res., 214-215, 106-123.

Letts, S., Torsvik, T.H., Webb, S.J. \& Ashwal, L.D., 2009. Palaeomagnetism of the 2054 Ma Bushveld Complex (South Africa): implications for emplacement and cooling, Geophys. J. Int., 179, 850-872.

Letts, S., Torsvik, T.H., Webb, S.J. \& Ashwal, L.D., 2010. New Palaeoproterozoic palaeomagnetic data from the Kaapvaal craton, South Africa, Geol. Soc. Lond., Spec. Publ., 357, 9-26.

Lowrie, W., 1990. Identification of ferromagnetic minerals in a rock by coercivity et unblocking temperature properties, Geophys. Res. Lett., 17, 159-162.

Lubnina, N., Ernst, R. E., Klausen, M. \& Söderlund, U., 2010. Paleomagnetic study of Neoarchean-Paleoproterozoic dykes in the Kaapvaal craton, Precambrian Res., 183, 523-552.

Mária, F., 2011. Handbook of the Thermogravimetric System of Minerals and its Use in Geological Practice, Vol. 213, Occasional Papers of the Geological Institute of Hungary, $180 \mathrm{pp}$.

Martin, D.M.B., Clendenin, C.W., Krapez, B. \& McNaughton, N.J., 1998. Tectonic andgeochronological constraints on Late Archaean and Palaeoproterozoic strati-graphic correlation within and between the Kaapvaal and Pilbara cratons, J. geol. Soc., 155, 311-322.

McFadden, P.L., 1990. A new fold test for palaeomagnetic studies, Geophys. J. Int., 103, 163-169.

McFadden, P.L. \& McElhinny, M.W., 1990. Classification of the reversal test in palaeomagnetism, Geophys. J. Int., 103, 725-729.

Miyano, T. \& Beukes, N.J., 1984. Phase relations of stilpnomelane, ferriannite, and riebeckite in very low-grade metamorphosed iron-formations, Trans. Geol. Soc. S. Afr., 87, 111-124.

Monecke, T., Renno, A.D. \& Herzig, P.M., 2004. Primary clinopyroxene spherulites in basaltic lavas from the Pacific-Antarctic Ridge, J. Volc. Geotherm. Res., 130, 51-59.

Moore, J.M., Tsikos, H. \& Polteau, S., 2001. Deconstructing the Transvaal Supergroup, South Africa: implications for Palaeoproterozoic palaeoclimate models, J. Afr. Earth Sci., 33, 437-444.

Moore, J.M., Polteau, S., Armstrong, R.A., Corfu, F. \& Tsikos, H., 2012. The age and correlation of the Postmasburg Group, southern Africa: constraints from detrital zircon grains, J. Afr. Earth Sci., 64, 9-19. 
Myers, R.E., Cawthorn, R.G., McCarthy, T.S. \& Anhaeusser, C.R., 1987. Fundamental uniformity in the trace element patterns of the volcanics of the Kaapvaal craton from 3000 to 2100 Ma: evidence for the lithospheric origin of these continental tholeiites, Geol. Soc. S. Afr., Spec. Publ., 33, 315-326.

Oberholzer, J.D., 1995. Die geologie van die piroklastiese gesteentes in die Hekpoort Formasie, Transvaal Opeenvolging, MSc thesis, University of Pretoria.

Oberholzer, J.D. \& Eriksson, P.G., 2000. Subaerial volcanism in the Palaeoproterozoic Hekpoort Formation (Transvaal Supergroup), Kaapvaal craton, Precambrian Res., 101, 193-210.

Olsson, J.R., Soderlund, U., Klausen, M.B. \& Ernst, R.E., 2010. U-Pb baddeleyite ageslinking major Archean dyke swarms to volcanic-rift forming events in theKaapvaal craton (South Africa), and a precise age for the Bushveld Complex, Precambrian Res., 183, 490-500.

Özdemir, Ö. \& Banerjee, S.K., 1984. High temperature stability of maghemite, Geophys. Res. Lett., 11, 161-164.

Pettersson, Å., Cornell, D.H., Moen, H.F.G., Reddy, S. \& Evans, D., 2007. Ion probe dating of $1.2 \mathrm{Ga}$ collision and crustal architecture in the Namaqua-Natal Province of southern Africa, Precambrian Res., 158, 79-92.

Pickard, A.L., 2003. SHRIMP U-Pb zircon ages for the Palaeoproterozoic KurumanIron Formation, Northern Cape Province, South Africa: evidence for simulta-neous BIF deposition on Kaapvaal and Pilbara Cratons, Precambran Res., 125, 275-315.

Rajesh, H.M., Chisonga, B.C., Shindo, K., Beukes, N.J. \& Armstrong, R.A., 2013. Petrographic, geochemical and SHRIMP U-Pb titanite age characterization of the Thabazimbi mafic sills: extended time frame and a unifying petrogenetic model for the Bushveld Large Igneous Province, Precambrian Res., 230, 79-102.

Reischmann, T., 1995. Precise U/Pb age determination with baddeleyite $\left(\mathrm{ZrO}_{2}\right)$, a case study from the Phalaborwa Igneous Complex, South Africa, S. Afr. J. Geol., 98, 1-4.

Salminen, J., Pesonen, L.J., Reimold, W.U., Donadini, D. \& Gibson, R.L., 2009. Paleomagnetic and rock magnetic study of the Vredefort impact structure and the Johannesburg Dome, Kaapvaal raton, South Africaimplications for the apparent polar wander path of the Kaapvaal raton during the mesoproterozoic, Precambrian Res., 168, 169-184.

Schröder, S., Beukes, N.J. \& Armstrong, R.A., 2016. Detrital zircon constraints on the tectonostratigraphy of the Paleoproterozoic Pretoria Group, South Africa, Precambrian Res., 278, 362-393.

Sharpe, M.R., Brits, R. \& Engelbrecht, J.P., 1983. Rare earth and trace element evidence pertaining to the petrogenesis of $2.3 \mathrm{Ga}$ old continental andesites and other volcanic rocks from the Transvaal Sequence, South Africa, Vol. 40, University of Pretoria Institute for Geological Research on the Bushveld Complex Research Report, 63 pp.
Sumner, D.Y. \& Bowring, S.A., 1996. U-Pb geochronologic constraints on deposition of the Campbellrand Subgroup, Transvaal Supergroup, South Africa, Precambrian Res., 79, 25-35.

Swanson-Hysell, N.L., Kilian, T.M. \& Hanson, R.E., 2015. A new grand mean paleomagnetic pole for the $1.11 \mathrm{Ga}$ Umkondo Large Igneous Province with implications for paleogeography and the geomagnetic field, Geophys. J. Int., 203, 2237-2247.

Tarling, D.H. \& Hrouda, F., 1993. The Magnetic Anisotropy of Rock, Chapman and Hall, $217 \mathrm{pp}$.

Torsvik, T.H. et al., 2012. Phanerozoic polar wander, paleogeography and dynamics, Earth-Sci. Rev., 114, 325-368.

Van der Voo, R., 1990. The reliability of paleomagnetic data, Tectonophysics, 184, 1-9.

Vollstädt, H., 1968. On the determination of rock-magnetic parameters by differential thermal analysis, Geophys. J. R. Astron. Soc., 16, 71-77.

Wabo, H., 2014. Paleomagnetism of post-Transvaal sill complexes, selected dykes and the Uitkomst Complex-relation to the Bushveld Complex, $P h D$ thesis, University of Johannesburg, Johannesburg, South Africa, 197 pp., unpublished.

Wabo, H., de Kock, M.O., Klausen, M., Söderlund, U. \& Beukes, N.J., $2016 a$. Paleomagnetism and chronology of B-1 marginal sills of the Bushveld Complex from the eastern Kaapvaal craton. South Africa, GFF, 138, 133 151.

Wabo, H., Olsson, J.R., De Kock, M.O., Humbert, F., Söderlund, U. \& Klausen, M., 2016b. New U-Pb age and paleomagnetic constraints from the Uitkomst Complex. South Africa: clues to the timing of intrusion, GFF, 138, 152-163.

Walraven, F. \& Hattingh, E., 1993. Geochronology of the Nebo Granite, Bushveld Complex, S. Afr. J. Geol., 96, 31-41.

Walraven, F. \& Martini, J., 1995. Zircon Pb-evaporation age determinations for the Oak Tree Formation, Chuniespoort Group. Transvaal sequence; implications for Transvaal-Griqualand West basin correlations, S. Afr. J. Geol., 98, 58-67.

Yang, W. \& Holland, H.D., 2003. The Hekpoort paleosol profile in Strata 1 at Gaborone, Botswana: soil formation during the Great Oxidation Event, Am. J. Sci., 303, 187-220.

Zeh, A., Ovtcharova, M, Wilson, A.H. \& Schaltegger, U., 2015. The Bushveld Complex was emplaced and cooled in less than one million years - results of zirconology, and geotectonic implications, Earth planet. Sci. Lett., 418, 103-114.

Zeh, A., Wilson, A.H. \& Ovtcharova, M., 2016. Source and age of upper Transvaal Supergroup, South Africa: age-Hf isotope record of zircons in Magaliesberg quartzite and Dullstroom lava, and implications for Paleoproterozoic (2.5-2.0 Ga) continent reconstruction, Precambrian Res., 268, $1-21$. 